\title{
合成構造フーチングを有するダブルラケット型 橋脚基礎の地震応答検証
}

\author{
伊原 茂 1 ・松崎 久倫 2 - 齋藤 隆 3 土屋 智史 4 ・斉藤 成彦 5 \\ 1正会員＼cjkstart首都高速道路（株） 保全・交通部保全技術課（†100-8930 東京都千代田区霞が関1-4-1） \\ E-mail: s.ihara72@shutoko.jp \\ 2正会員 首都高速道路(株) プロジェクト部改築設計課（テ100-8930 東京都千代田区霞が関1-4-1） \\ E-mail: h.matsuzaki1113@shutoko.jp \\ 3正会員 (株) 大林組 生産技術本部設計第一部設計第四課（干108-8502 東京都港区港南2-15-2） \\ E-mail: saito.takashi@obayashi.co.jp \\ 4正会員 （株）コムスエンジニアリング（†113-0023 東京都文京区向丘1-1-17） \\ E-mail: satoshi@comse.co.jp \\ 5正会員 山梨大学准教授 大学院医学工学総合研究部（干400-8511 山梨県甲府市武田4-3-11） \\ E-mail: ssaito@yamanashi.ac.jp
}

供用下においてラケット型橋脚で支持されたダブルデッキ高架橋の上下層を拡幅するには，既設橋脚の 前後にラケット型鋼製橋脚を新設し, 既設橋脚を撤去するサンドイッチ工法が有効である. そのため, 新 設鋼製橋脚の新たな定着構造である鋼製格子部材を埋設した新設フーチングと既設フーチングを一体化さ せた合成構造フーチングを考案し，その耐荷性能を検証してきた。本論文では，その合成構造フーチング， ダブルラケット型鋼製橋脚，基礎杭からなる下部構造系の性能を設定した上で，レベル2地震動時を想定 した構造物一地盤連成系の2次元静的・動的非線形FEM解析を行い，各構造部位の損傷状況を分析し，性 能検証を行った。さらには，本解析結果を踏まえ，現場制約条件下にある既設構造物と一体化する下部構 造系の設計のあり方について方向性を述べる.

Key Words : coupled nonlinear dynamic response analysis, hybrid structural footing, double racket-type steel piers, load bearing capacity

\section{1. はじめに}

2015年3月，首都高速中央環状品川線約 $9.4 \mathrm{~km}$ が開通し， 首都圈3環状道路のうち最初に首都高速中央環状線が全 線約 $47 \mathrm{~km}$ 開通した。首都高速道路では，開通後におけ る交通の流れの変化に伴う中央環状線の渋帯発生に備え, 既に板橋・熊野町ジャンクション間および堀切・小菅ジ ヤンクション間における車道拡幅工事に着手している.

供用後約38年が経過する中央環状線の板橋・熊野町ジ ヤンクション間では，供用下においてラケット型橋脚で 支持されたダブルデッキ高架橋の上・下層を3車線から4 車線に片側最大約 $1.7 \mathrm{~m}$ 拡幅する。 しかし，交通量約 95 万 台／日の首都圈の大動脈である首都高速道路を長期間通 行止めして車道を拡幅することは，社会的影響が大きく 困難である.

そこで，図-1，図-2に示すとおり，ラケット型既設橋
脚の前後に拡幅量を確保した一回り大きいラケット型鋼 製橋脚を新設し，支点を受替えた後に既設橋脚を撤去す るサンドイッチ工法が適用できるように，合成構造フー チングを開発した．合成構造フーチングとは，新設鋼製 橋脚を支持する従来のアンカーフレーム方式に代わる鋼 製格子部材を埋設した新設フーチングと既設フーチング を一体化させたものである。これまで合成構造フーチン グについては実構造物の1/5スケールの試験体を用いた 橋軸方向および橋軸直角方向の載荷実験によりレベル2 地震動時相当荷重に対して十分に耐荷性能を有すること が検証されている1),2).

しかしながら，レベル2地震動時における既設場所打 ち杭の杭頭部におけるせん断破壊および既設フーチング の鉄筋降伏の可能性が懸念された。 また，新設橋脚はサ ンドイッチ工法によりダブルラケット型橋脚となるため 剛性が大きくなる.これに対して，新設杭は供用下施工 
のため，既設杭の外側でしかも街路制約条件の下，橋脚 中心から離れた橋軸方向に構築せざるを得なく，新設杭 の断面寸法は限定される. その結果，レベル2地震動時 における既設杭および新設杭の降伏を許容するが，合成 構造フーチングを含めた基礎全体としては降伏しないこ ととした.さらに，鋼製格子部材は新設フーチングに埋 設されるため, 剛結している新設橋脚基部よりも先行し て降伏することは回避する必要がある．以上の性能を検 証するためには，合成構造フーチングだけでなくダブル ラケット型橋脚，既設杭，新設杭，杭の挙動に影響を及 ぼす周辺地盤を含めた下部構造系を対象に，レベル2地 震動時における各構造部位の損傷状況を分析しなければ ならない. 図-3に板橋・熊野町ジャンクション間におけ
る地盤構成の一部を示す.

近年，牧ら ${ }^{33) 4}$ は，実在する道路橋橋台を対象にRC杭 基礎と地盤の連成系地震応答解析について研究しており, 2次元FEMモデルと3次元FEMモデルによる解析結果の比 較検討も実施している，その結果，2次元モデルにおけ る地盤の奥行き設定をフーチング幅程度にすれば，工学 的には3次元解析と概小等価であると推定されている.

以上を踏まえ，岡村，前川ら5によって開発されたRC 構造物に関して実積のある2次元非線形FEM解析コード

（WCOMD）を用いて，レベル2地震動時における構造 物一地盤連成系の2次元静的・動的非線形FEM解析を実 施した. 具体的には，合成構造フーチングの載荷実験と 同じ条件で2次元静的非線形FEM解析を行い，解析コー

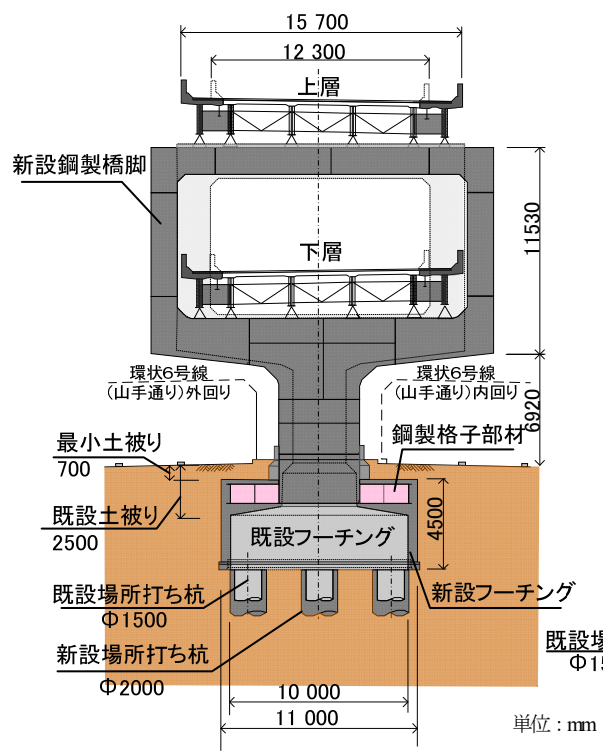

(a) 橋軸直角方向

図-1サンドイッチ工法および合成構造フーチン

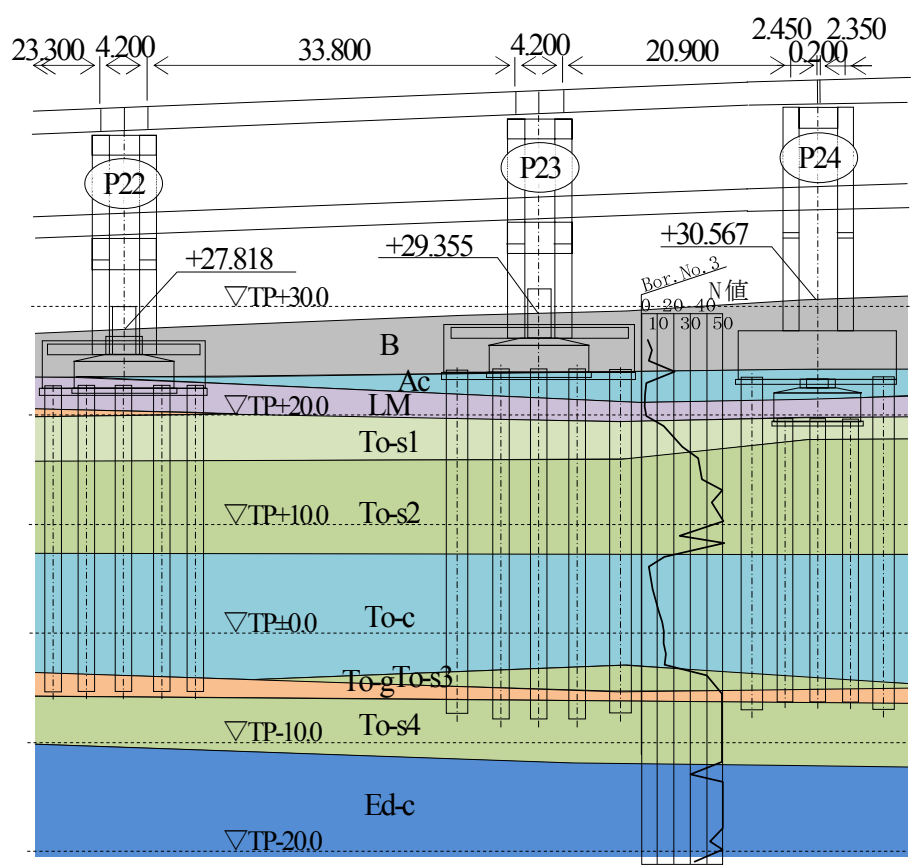

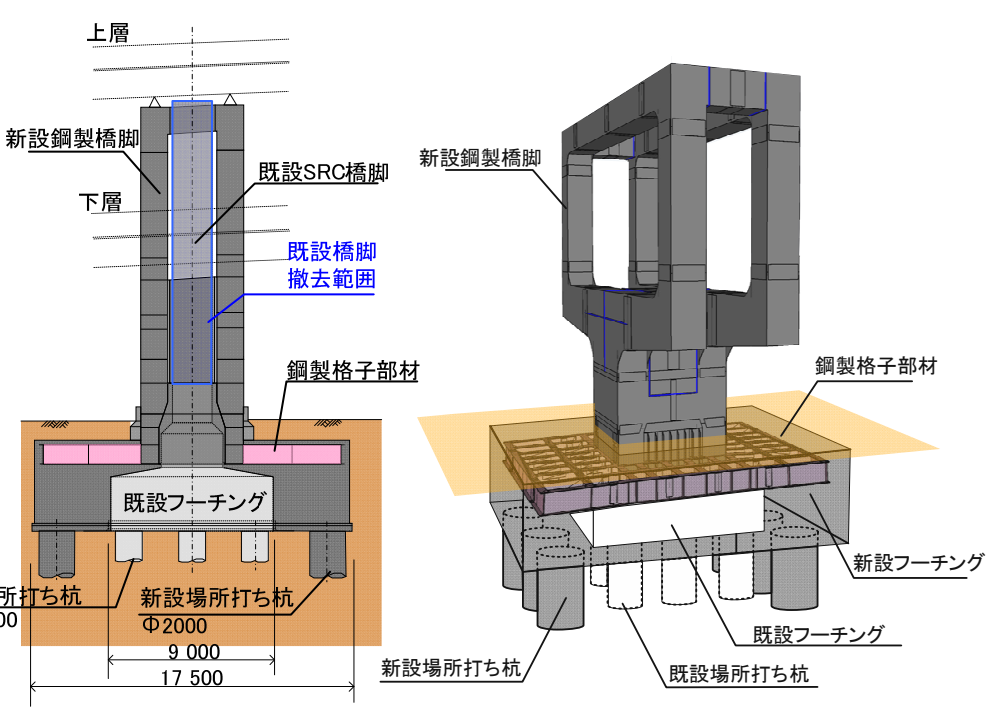

図-2＼cjkstart既設橋脚撤去後の完成概要図

凡例

\begin{tabular}{|c|c|c|}
\hline \multicolumn{2}{|c|}{ 地層名 } & 記号 \\
\hline \multicolumn{2}{|c|}{ 盛土層 } & B \\
\hline \multicolumn{2}{|c|}{ 沖積粘性土層 } & Ac \\
\hline \multicolumn{2}{|c|}{ ローム層 } & LM \\
\hline \multirow{6}{*}{ 東京層 } & 第 1 砂質土層 & To-s1 \\
\hline & 第2砂質十層 & To-s2 \\
\hline & 粘性土層 & Toc \\
\hline & 第3砂質土層 & To-s3 \\
\hline & 砂磼土層 & To-g \\
\hline & 第4砂質土層 & To-s4 \\
\hline 江戸川層 & 粘性土層 & $E d-c$ \\
\hline
\end{tabular}

単位 : m

図-3 板橋・熊野町ジャンクション間における地盤構成図 
ドの妥当性を確認した上で，実構造物サイズのダブルラ ケット型鋼製橋脚，合成構造フーチング，基礎杭および 周辺地盤を含めた構造物一地盤連成系を対象に，2次元 静的・動的非線形FEM解析を実施した. レベル2地震動 を想定して, 静的解析では, 各構造部位の損傷過程およ び基礎全体としての降伏の有無，動的解析では，レベル 2地震動における動的応答特性, 各構造部位の損傷状況, 基礎全体としての降伏の有無等について検証した. さら には，本解析結果を踏まえ，厳しい現場制約条件下にあ る首都高速道路のような都市高速道路高架橋の下部構造 系の設計のあり方についてその方向性を述べる.

\section{2. 合成構造フーチングの実験再現解析}

実構造物と同じスケールの構造物一地盤連成系解析に 先立ち，解析コードおよびモデル化の妥当性を検証する ために，橋軸方向載荷実験と同じ条件で WCOMD によ る2次元静的非線形 FEM解析を実施した.

\section{(1) 実験概要}

合成構造フーチングの載荷実験 ${ }^{122}$ について, 以下に, その要約を述べる. 試験体は, 載荷装置の能力等を考慮 し，実構造物の $1 / 5$ モデルとしている，ただし，橋脚お

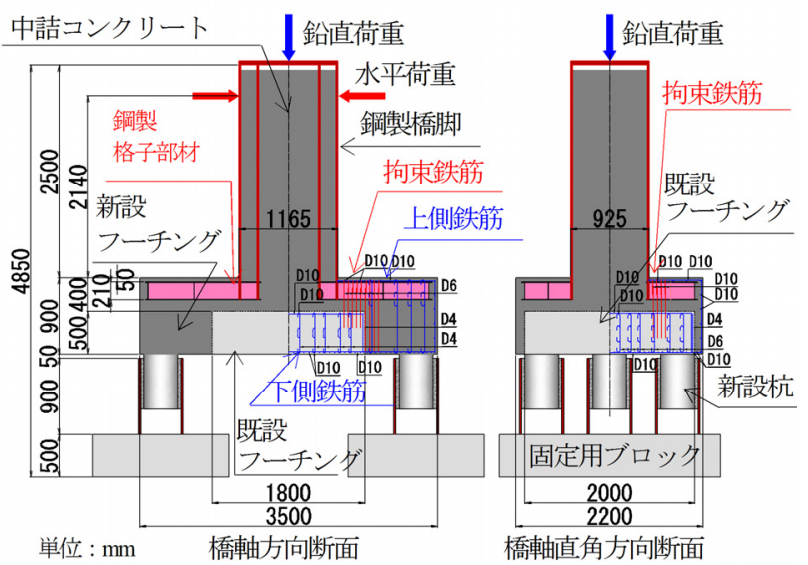

図-4 試験体構造図および配笳図 ${ }^{2}$

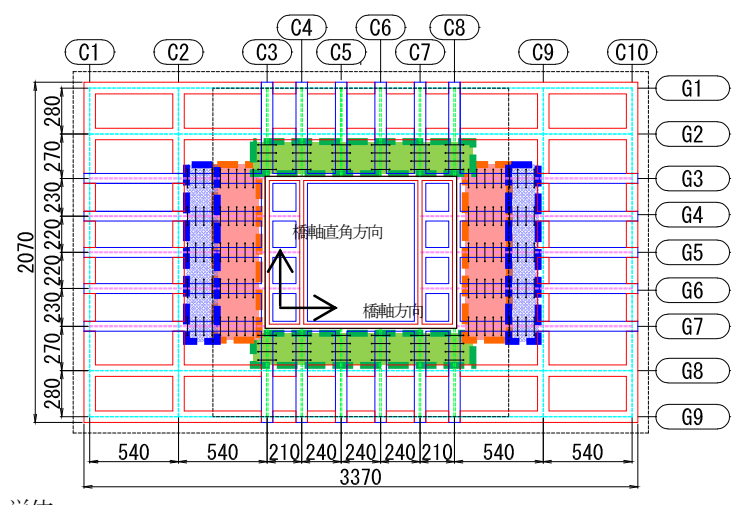

単位: $\mathrm{mm}$

図-5 鋼製格子部材と拘束鉄筋 2
よび新設杭は，本実験の着目部位である橋脚とフーチン グの結合部より先に降伏しないように設計されている. また，検討対象の実構造物では既設杭がレベル 2 地震動 時に杭頭部でせん断破壊することが想定されるため，実 験では鋼製格子部材にとって不利になる条件を考えて既 設杭のモデル化は行われていない.

図-4 に試験体構造図および配筋図を示す，フーチン グ長辺方向が橋軸方向，短辺方向が橋軸直角方向である. 実構造物と同様に，既設フーチング部を製作した後に新 旧コンクリートの一体化を図るために, 目標付着強度を $1.5 \mathrm{~N} / \mathrm{mm}^{2}$ とし，打継ぎ面の表面処理を行っている．鋼製 格子部材は，写真-1 に示すとおり，鋼製橋脚と溶接によ り接合し，新設部のコンクリート打設により埋設するこ とで，一体化が図られている. 図-5 に平面図，表-1 に 使用材料および材料試験結果を示す.

図-6に拘束鉄筋の詳細図を示寸，拘束鉄筋は，鋼製 格子部材およびフーチング上側鉄筋を取り囲むようにし て配置されている，既設フーチング部への埋込み長は鉄 筋継手長の算出式より $31 D(D$ : 鉄筋径 $)$ とし, 新設 ーチングの拘束鉄筋はフーチング下側鉄筋まで埋込まれ ている．鉛直荷重は，実橋脚基部におけるレベル 2 地震 動時の鉛直荷重をもとに $700 \mathrm{kN}$ ，水平荷重は，せん断力 より $P_{\mathrm{LL}}=848 \mathrm{kN}$ と定め, 載荷履歴は正負交番載荷後, 片側に単調載荷させている.

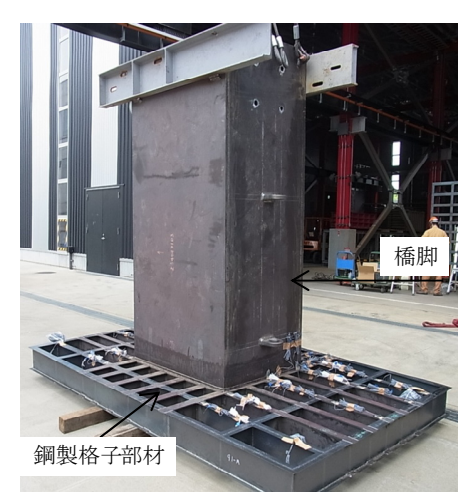

写真-1 鋼製格子部材と橋脚 1$)$

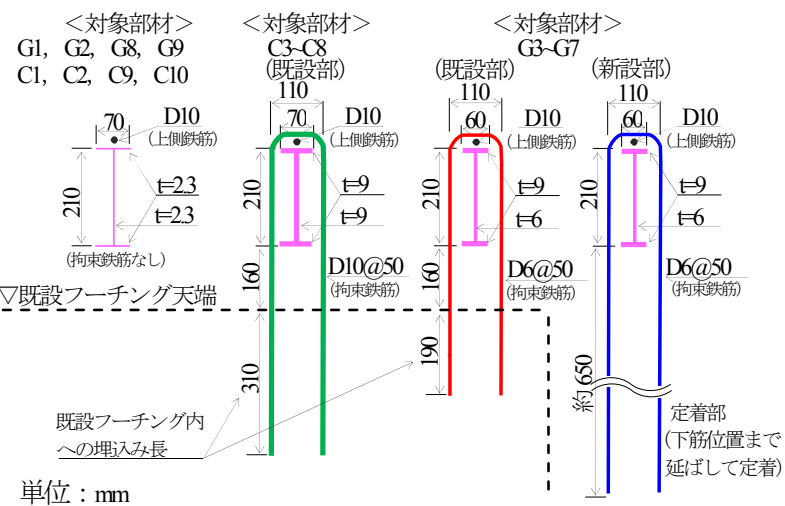

図-6 拘束鉄筋の詳細図 ${ }^{2)}$ 
表-1 鋼製格子部材の使用材料および材料試験結果

\begin{tabular}{|c|c|c|c|c|c|c|}
\hline 鋼製格子部材 & 部位 & 鋼種 & $\begin{array}{l}\text { 板厚 } \\
(\mathrm{mm})\end{array}$ & $\begin{array}{l}\begin{array}{c}\text { 板幅 } \\
(\mathrm{mm})\end{array} \\
\end{array}$ & $\begin{array}{r}\text { 降伏強度 } \\
\left(\mathrm{N} / \mathrm{mm}^{2}\right) \\
\end{array}$ & $\begin{array}{c}\text { ヤング係数 } \\
\left(\mathrm{kN} / \mathrm{mm}^{2}\right)\end{array}$ \\
\hline \multirow{2}{*}{ G1,G2,G8,G9 } & フランジ & \multirow{2}{*}{ SS400 } & \multirow{2}{*}{2.3} & 70 & \multirow{2}{*}{368} & \multirow{2}{*}{210} \\
\hline & ウェブ & & & 210 & & \\
\hline \multirow{2}{*}{$\mathrm{G} 3 \sim \mathrm{G} 7$} & フランジ & \multirow{2}{*}{ SM490Y } & 9 & 60 & 413 & 211 \\
\hline & ウェブ & & 6 & 210 & 400 & 211 \\
\hline \multirow{2}{*}{$\mathrm{C} 1, \mathrm{C} 2, \mathrm{C} 9, \mathrm{C} 10$} & フランジ & \multirow{2}{*}{ SS400 } & \multirow{2}{*}{2.3} & 70 & \multirow{2}{*}{368} & \multirow{2}{*}{210} \\
\hline & ウェブ & & & 210 & & \\
\hline \multirow{2}{*}{$\mathrm{C} 3 \sim \mathrm{C} 8$} & フランジ & \multirow{2}{*}{ SM490Y } & \multirow{2}{*}{9} & 70 & \multirow{2}{*}{413} & \multirow{2}{*}{211} \\
\hline & ウェブ & & & 210 & & \\
\hline
\end{tabular}

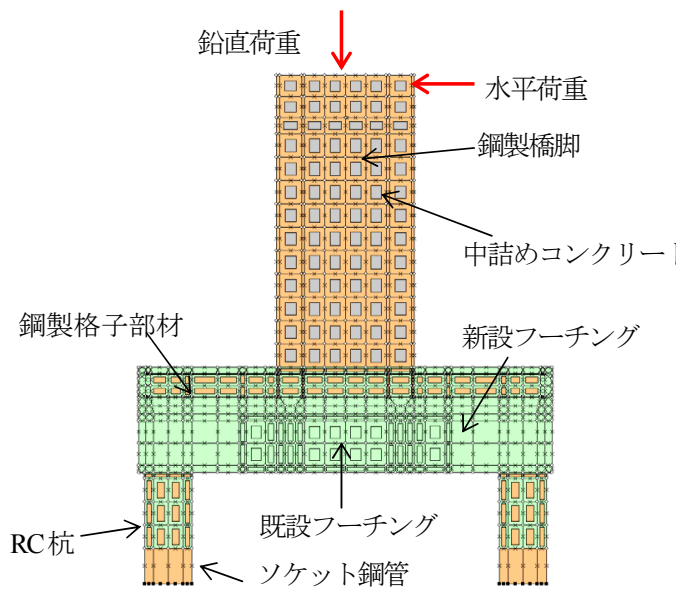

(a) 解析モデル

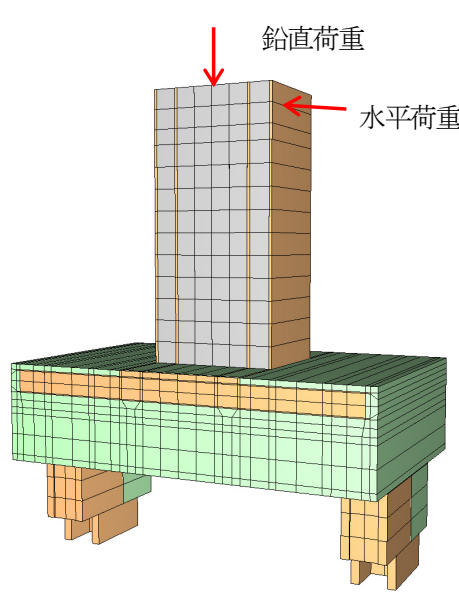

(b) 擬似的に 3 次元表示した解析モデル

図-7 載荷実験の 2 次元静的非線形 EEM解析モデル

\section{(2) 解析概要}

図-7 に解析モデルを示す.WCOMD は分散ひび割れ モデルに基づく RC の履歴依存型非線形材料構成則を用 いており, 鉄筋はコンクリートに埋め込まれた RC 要素 としてモデル化されている. また，オーバーラップ要素 により奥行きを考慮することができる ${ }^{9}$. RC 要素のメ ッシュ分割は，軟化領域内のコンクリートの応力ーひず み関係に及ぼす影響が少ないことが確認されている 200 $\mathrm{mm}$ を標準とした ${ }^{7}$. 実験試験体のうち, 合成構造フー チングと場所打ち杭を $\mathrm{RC}$ 要素，橋脚内の中詰めコンク リートを無筋要素でモデル化した．各部位の RC 要素お よび無筋要素には，表-2 に示す材料特性に基づく非線 形の材料構成則を用いた. なお，付着パラメータ $c$ は, 十分な鉄筋比を有する場合は 0.4 とし, 無筋要素の場合 は，破壊エネルギー $G_{F}$ に応じた值を設定した.

解析モデルにおいては， RC 杭は杭断面を 4 分割とし, $\mathrm{RC}$ 杭の円形断面を矩形断面の集合として近似した.こ のときの矩形断面の形状は， RC 杭の円形のコンクリー 卜全断面に対して断面積および断面二次モーメントが一 致するように設定し, $\mathrm{RC}$ 杭と岡結するソケット鋼管に ついても同様とした．鋼製格子部材は，鋼材の引張試験 により得られたヤング係数の弾性要素, 鋼製橋脚はヤン グ係数 $E=200 \mathrm{kN} / \mathrm{mm}^{2}$ の弾性要素によりモデル化した.
鋼製格子部材のモデル化においては，フランジ幅につ いては，最も厚い鋼板厚を基準に断面が各部材と等価と なるように定め, ウェブ厚さは，各部材のウェブ厚の合 計とし，モデル化する方向に直交して配置される鋼製格 子部材の剛性は考慮しないこととした.

本解析では載荷実験と同様に，700 kN の鉛直荷重を橋 脚天端に載荷させて, 水平荷重作用位置に対して水平方 向強制変位によるプッシュオーバー解析を実施した.

\section{(3) 解析結果}

図-8に荷重一載荷点変位関係，表-3にフーチングコン クリート初ひび割れ，拘束鉄筋初降伏，フーチング上側 鉄筋初降伏，鋼製格子部材初降伏の発生荷重に関して, 実験・解析結果を示す.コンクリートの初ひび割れの発 生荷重および最大荷重は実験と比較して大きい值を示し ているが，拘束鉄筋・上側鉄筋・鋼製格子部材の初降伏 については概ね致している.

一方，ひび割れ開口については，載荷点変位 $5.25 \mathrm{~mm}$ のときに橋脚基部引張側の鋼製格子部材下フランジ付近 で発生し, 荷重増加に伴い下フランジに沿って水平に連 続してひび割れが開口する挙動が確認された。図-9 と 図-10 は最大荷重（変位 $64.8 \mathrm{~mm}$ 時）におけるひび割れ 開口ひずみ分布および主ひずみコンター図を示す. 
表-2ＲC部材の材料特性值（実験再現解析）

\begin{tabular}{|c|c|c|c|c|c|c|c|c|}
\hline & & \multirow{2}{*}{\multicolumn{2}{|c|}{ 項 目 }} & \multirow{2}{*}{ 単位 } & \multicolumn{2}{|c|}{ フーチング } & \multirow{2}{*}{ 杭 } & \multirow{2}{*}{$\begin{array}{c}\text { 橋脚 } \\
\text { 中詰め }\end{array}$} \\
\hline & & & & & 新設部 & 既設部 & & \\
\hline \multirow{7}{*}{\multicolumn{2}{|c|}{ コンクリート }} & 圧縮強度 & $f^{\prime}{ }_{c}$ & $\mathrm{~N} / \mathrm{mm}^{2}$ & 25.6 & 28.6 & 33.1 & 27.5 \\
\hline & & 引張強度 & $\bar{f}$ & $\mathrm{~N} / \mathrm{mm}^{2}$ & 1.74 & 2.03 & 2.37 & 1.78 \\
\hline & & 単位重量 & $\gamma$ & $\mathrm{kN} / \mathrm{m}^{3}$ & 23.0 & 23.0 & 23.0 & 23.0 \\
\hline & & 圧縮ピーク歪 & $\varepsilon_{\text {peak }}^{\prime}$ & $\%$ & 0.200 & 0.200 & 0.200 & 0.200 \\
\hline & & ひび割れーせん断伝達係数 & $\alpha$ & - & 1 & 1 & 1 & 1 \\
\hline & & 粗骨材の最大寸法 & $d_{\max }$ & $\mathrm{mm}$ & 25 & 25 & 25 & 25 \\
\hline & & 破壊エネルギー & $G_{F}$ & $\mathrm{~N} / \mathrm{m}$ & 0.086 & 0.089 & 0.094 & 0.088 \\
\hline \multirow{12}{*}{ 鉄筋 } & \multirow{3}{*}{ D4 } & ヤング係数 & $E_{s}$ & $\mathrm{kN} / \mathrm{mm}^{2}$ & - & 203 & - & - \\
\hline & & 降伏強度 & $f_{s y}$ & $\mathrm{~N} / \mathrm{mm}^{2}$ & - & 362 & - & - \\
\hline & & 単位重量 & $\gamma$ & $\mathrm{kN} / \mathrm{m}^{3}$ & - & 77.0 & - & - \\
\hline & \multirow{3}{*}{ D6 } & ヤング係数 & $E_{s}$ & $\mathrm{kN} / \mathrm{mm}^{2}$ & 194 & - & - & - \\
\hline & & 降伏強度 & $f_{s y}$ & $\mathrm{~N} / \mathrm{mm}^{2}$ & 407 & - & - & - \\
\hline & & 単位重量 & $\gamma$ & $\mathrm{kN} / \mathrm{m}^{3}$ & 77.0 & - & - & - \\
\hline & \multirow{3}{*}{$\begin{array}{c}\text { D10 } \\
\text { (SD295) }\end{array}$} & ヤング係数 & $E_{s}$ & $\mathrm{kN} / \mathrm{mm}^{2}$ & - & 192 & - & - \\
\hline & & 降伏強度 & $f_{s y}$ & $\mathrm{~N} / \mathrm{mm}^{2}$ & - & 343 & - & - \\
\hline & & 単位重量 & $\gamma$ & $\mathrm{kN} / \mathrm{m}^{3}$ & - & 77.0 & - & - \\
\hline & \multirow{3}{*}{$\begin{array}{c}\text { D10 } \\
\text { (SD345) }\end{array}$} & ヤング係数 & $E_{s}$ & $\mathrm{kN} / \mathrm{mm}^{2}$ & 193 & - & - & - \\
\hline & & 降伏強度 & $f_{s y}$ & $\mathrm{~N} / \mathrm{mm}^{2}$ & 375 & - & - & - \\
\hline & & 単位重量 & $\gamma$ & $\mathrm{kN} / \mathrm{m}^{3}$ & 77.0 & - & - & - \\
\hline
\end{tabular}

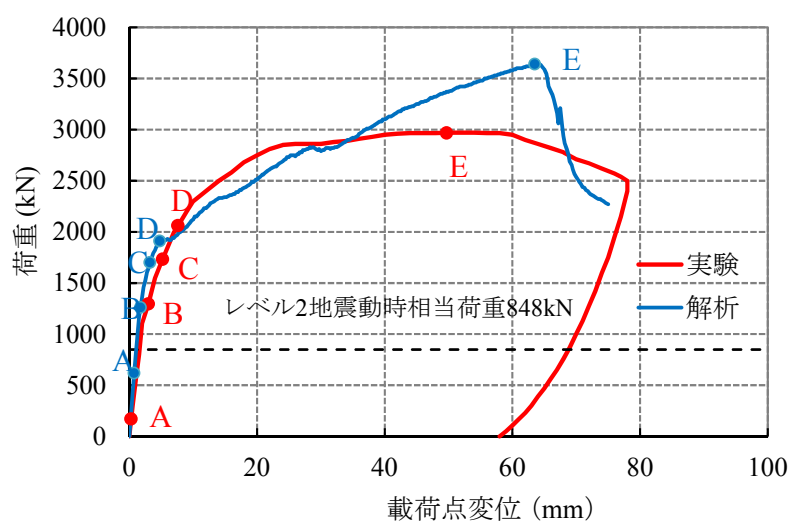

図-8 荷重一載荷点変位関係

表-3 初ひび割れ・初降伏の発生荷重

\begin{tabular}{|r|l|r|r|}
\hline \multicolumn{2}{|c|}{ イベント } & \multicolumn{1}{c|}{ 実験 } & \multicolumn{1}{c|}{ 解析 } \\
\hline $\mathrm{A}$ & \multicolumn{1}{|c|}{ コンクリート初ひび割れ } & 170 & 617 \\
\hline $\mathrm{B}$ & 拘束鉄筋初降伏 & 1,295 & 1,260 \\
\hline $\mathrm{C}$ & 上側鉄筋初降伏 & 1,731 & 1,700 \\
\hline $\mathrm{D}$ & 鋼製格子部材初降伏 & 2,060 & 1,910 \\
\hline $\mathrm{E}$ & 最大荷重 & 2,967 & 3,640 \\
\hline
\end{tabular}

載荷実験によりフーチング側面に発生した鋼製格子部 材下フランジに沿った割裂と一致している. 以上より, レベル 2 地震動相当荷重の約 $150 \%$ までの荷重一変位関 係および鋼製格子部材に沿った大きな割裂等の再現性か ら，合成構造フーチングのモデル化は適切であると考え られる.

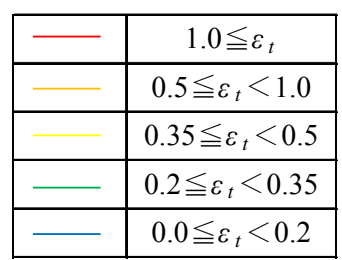

$\varepsilon_{t}:$ ひび割れ開口ひずみ

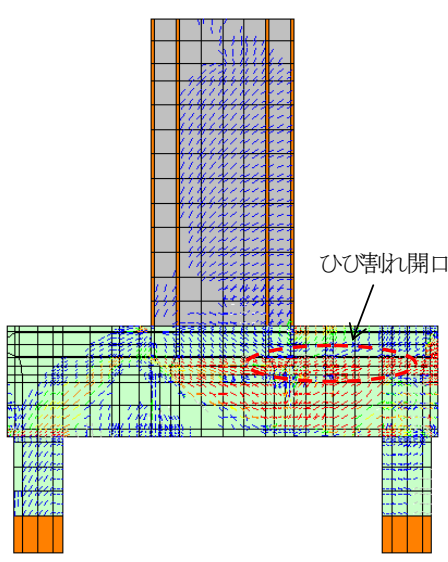

図-9＼cjkstart最大荷重時のひび割れ開口ひずみ分布図

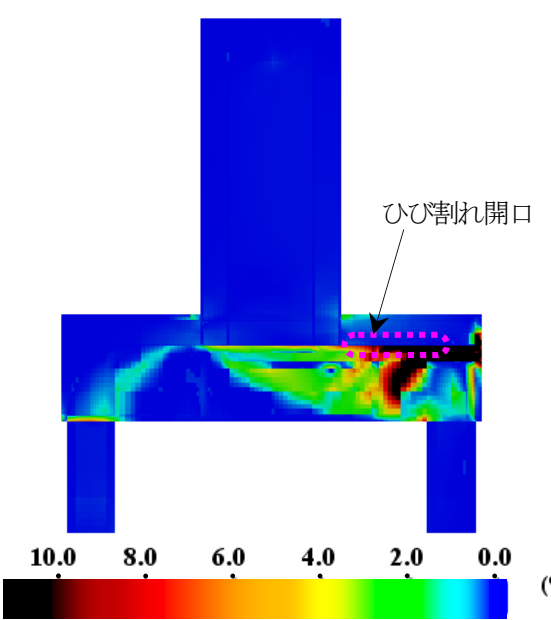

図-10 最大荷重時の主ひずタコンター図 


\section{2 次元連成系静的非線形 FEM 解析}

上述のとおり, WCOMD の解析コードの妥当性が確 認できたので，以下においては，実構造物と同じスケー ルで橋軸方向および橋軸直角方向に各々レベル 2 地震動 時相当荷重を想定して構造物一地盤連成系 2 次元静的非 線形 FEM解析を行うこととした.

\section{(1) 解析概要}

橋脚の中詰めコンクリートおよび合成構造フーチング の要素メッシュ分割は， $500 \mathrm{~mm}$ 以下を目安とした。 そ の他については，実験再現解析と同様である. 表-4 に $\mathrm{RC}$ 要素および無筋要素に適用する材料特性を示す. 図11 にダブルラケット型新設鋼製橋脚の断面寸法および 鋼板厚, 表-5 に合成構造フーチング内に配置される鋼 製格子部材の諸元，図-12 に合成構造フーチングの平面 図を示寸。

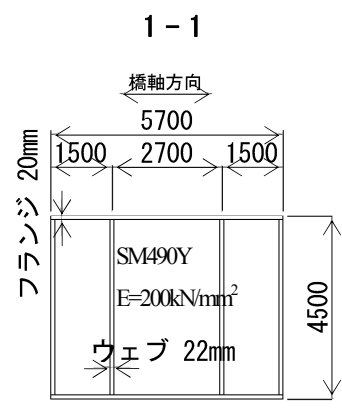

(a) 一般部
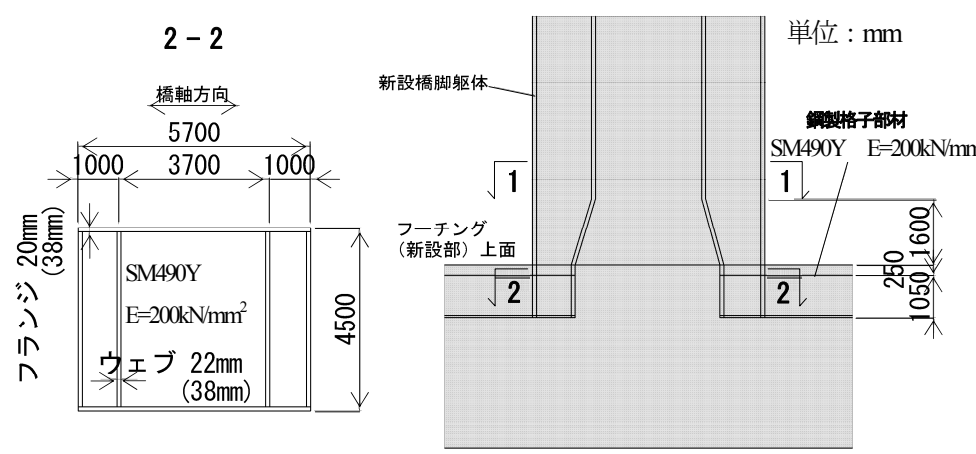

(b) 基部（鋼製格子部材付近）

図-11ダブルラケット型新設鋼製橋脚の断面図

表-4 RC 部材の材料特性值（2次元静的非線形 FEM 解析）

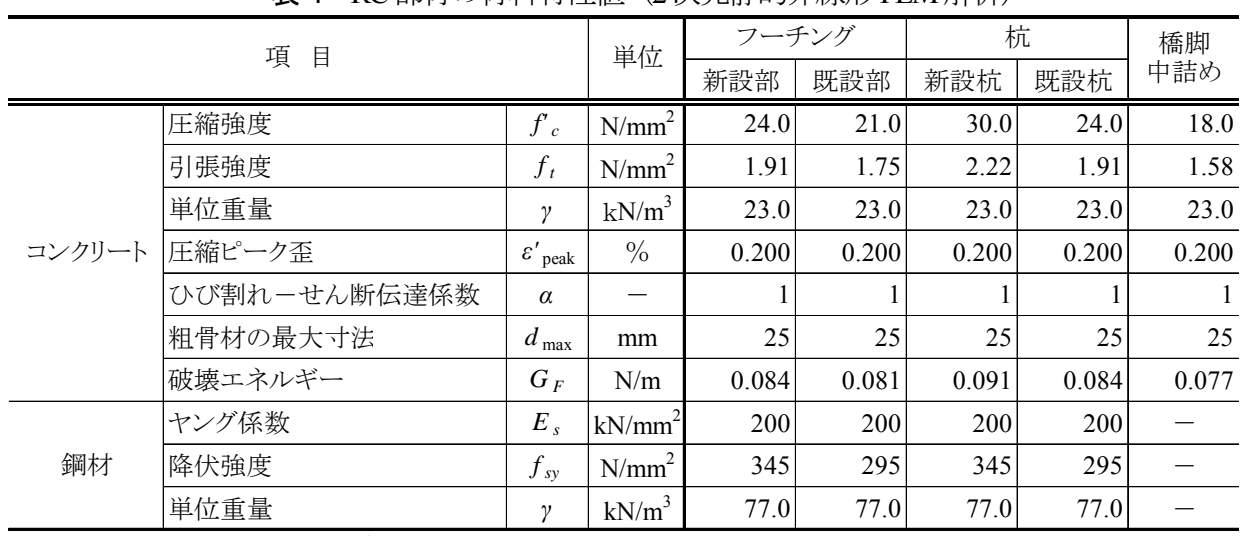

表-5 鋼製格子部材の諸元

\begin{tabular}{|c|c|c|c|c|c|c|c|c|c|c|}
\hline & & \multirow{2}{*}{\multicolumn{2}{|c|}{ 対 象 }} & \multirow{2}{*}{$\begin{array}{c}\text { 部材数 } \\
\text { (本) }\end{array}$} & \multirow{2}{*}{$\begin{array}{l}\text { 桁高 } \\
(\mathrm{mm})\end{array}$} & \multicolumn{3}{|c|}{ 上下フランジ } & \multicolumn{2}{|c|}{ ウェブ } \\
\hline & & & & & & $\begin{array}{c}\text { 幅 } \\
(\mathrm{mm})\end{array}$ & $\begin{array}{l}\text { 厚さ } \\
(\mathrm{mm})\end{array}$ & $\begin{array}{l}\text { 面積 } \\
\left(\mathrm{mm}^{2}\right)\end{array}$ & $\begin{array}{l}\text { 厚さ } \\
(\mathrm{mm})\end{array}$ & $\begin{array}{r}\text { 厚さ計 } \\
(\mathrm{mm})\end{array}$ \\
\hline \multirow{6}{*}{ 橋軸方向 } & \multirow{3}{*}{ 一般部 } & \multirow{2}{*}{ 配置鋼材 } & G1, 2, 8, 9桁 & 4 & 1050 & 350 & 10 & \multirow{2}{*}{63000} & 9 & \multirow{2}{*}{226} \\
\hline & & & G3 G7桁 & 5 & 1050 & 350 & 28 & & 38 & \\
\hline & & 解析モデル & G1〜9析合計 & - & 1050 & 2250 & 28 & 63000 & 226 & 226 \\
\hline & \multirow{3}{*}{ 橋脚柱部 } & \multirow{2}{*}{ 配置鋼材 } & $\mathrm{G} 1,2,8,9$ 桁 & 4 & 1050 & 350 & 10 & \multirow{2}{*}{33600} & 9 & \multirow{2}{*}{112} \\
\hline & & & G3, 7桁 & 2 & 1050 & 350 & 28 & & 38 & \\
\hline & & 解析モデル & G1～9桁合計 & - & 1050 & 1200 & 28 & 33600 & 112 & 112 \\
\hline \multirow{6}{*}{$\begin{array}{c}\text { 橋軸直角 } \\
\text { 方向 }\end{array}$} & \multirow{3}{*}{ 一般部 } & \multirow{2}{*}{ 配置鋼材 } & $\mathrm{C} 1,2,9,10$ 桁 & 4 & 1050 & 350 & 10 & \multirow{2}{*}{72800} & 9 & \multirow{2}{*}{264} \\
\hline & & & C3〜8桁 & 6 & 1050 & 350 & 28 & & 38 & \\
\hline & & 解析モデル & $\mathrm{C} 1 \sim 10$ 桁合計 & - & 1050 & 2600 & 28 & 72800 & 264 & 264 \\
\hline & \multirow{3}{*}{ 橋脚柱部 } & \multirow{2}{*}{ 配置鋼材 } & $\mathrm{C} 1,2,9,10$ 桁 & 4 & 1050 & 350 & 10 & \multirow{2}{*}{53200} & 9 & \multirow{2}{*}{188} \\
\hline & & & C3〜8桁 & 4 & 1050 & 350 & 28 & & 38 & \\
\hline & & 解析モデル & $\mathrm{C} 1 \sim 10$ 桁合計 & - & 1050 & 1900 & 28 & 53200 & 188 & 188 \\
\hline
\end{tabular}


地盤要素の構成モデルには，間隙水圧の変動を考慮し ない全応力に基づく定式化を採用し，偏差応力一偏差ひ

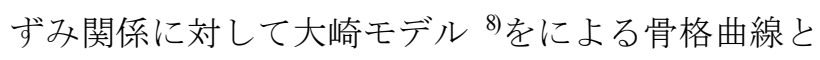
Masing 則に基づく履歴則を適用した．なお，体積成分に ついては線形弾性の仮定の下，拘束圧の変動幅は小さい と考え, 拘束圧変動によるせん断強度の変化および繰返 しせん断に起因するダイレイタンシーは考慮しないこと とした. 表-6に当該拡幅工事区間において最もスパン の長い上部工を支持し, 合成構造フーチングのプロトタ イプである P23 橋脚の地質条件を示す．初期せん断岡性 $G_{0}$, せん断強度 $S_{u}$ などの材料物性值は現場における地 質調査結果より得られた $N$ 值に基づいて, 次式により 算定した ${ }^{9,10)}$.

$$
G_{0}=11.76 N^{0.8}
$$

$S_{u}=G_{0} / 600\left(\mathrm{~N} / \mathrm{mm}^{2}\right) \quad$ : 粘性土 $S_{u}=G_{0} / 850\left(\mathrm{~N} / \mathrm{mm}^{2}\right)$ : 砂質粘性土 $S_{u}=G_{0} / 1100\left(\mathrm{~N} / \mathrm{mm}^{2}\right) ：$ 砂質土
(1)
ここに, $N$ : 標準貫入試験から得られる $N$ 值, $G_{0}$ : 初期 せん断岡性, $S_{u}$ : せん断強度とする.

構造物一地盤連成系解析を行う場合, 構造物と地盤の 境界面における相互作用のモデル化が重要である．RC フーチング・RC 杭と地盤の間にはジョイント要素を設 けた。 図-13 にジョイント要素の概念図 ${ }^{11}$ を示す。接触 剛性については, RC 要素が地盤要素に重ならないよう に十分剛な $10 \mathrm{kN} / \mathrm{mm}^{2} / \mathrm{mm}$ とし, 開口時には接触方向の 剛性は 0 とした. せん断抵抗については, 剥離時にはせ 几断岡性を 0 とし, 接触時のみせん断抵抗が生じるよう に, 鉄道構造物等設計標準 ${ }^{12)}$ に準拠して設定した.

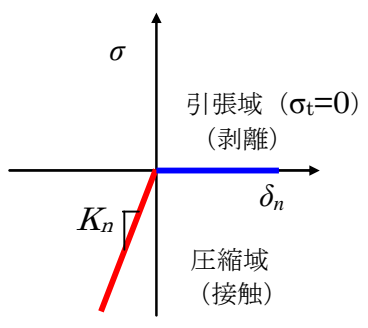

(a) 垂直方向

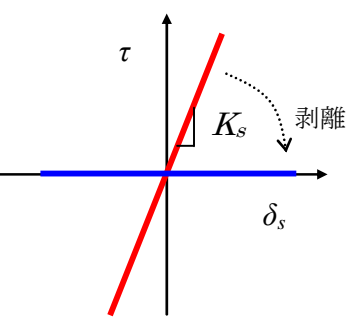

(b) せん断方向
図-13ジョイント要素の概念図 本位 : mm

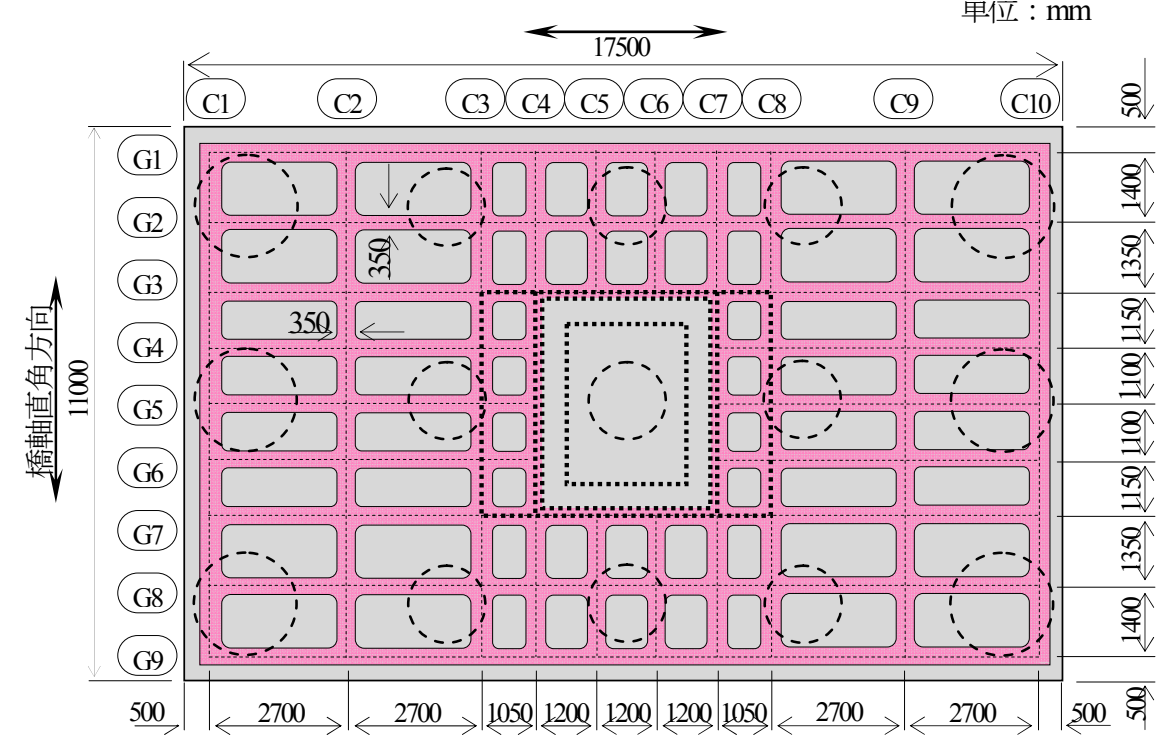

図-12 合成構造フーチングの平面図

表-6 地盤条件

\begin{tabular}{c|c|c|c|c|c|c|c|c|c|c}
\hline \multirow{2}{*}{ 地層 } & \multirow{2}{*}{ 記号 } & \multicolumn{2}{|c|}{ 標高 $(\mathrm{TP} \pm \mathrm{m})$} & \multirow{2}{*}{ 層厚 $(\mathrm{m})$} & \multirow{2}{*}{$N$ 值 } & $\begin{array}{c}\text { 単位体積重量 } \\
\gamma\left(\mathrm{kN} / \mathrm{m}^{3}\right)\end{array}$ & 地盤種別 & $\begin{array}{c}\text { せん断弾性係数 } \\
G_{0}\left(\mathrm{~N} / \mathrm{mm}^{2}\right)\end{array}$ & $\begin{array}{c}\text { せん断強度 } \\
S_{u}\left(\mathrm{~N} / \mathrm{mm}^{2}\right)\end{array}$ & $\begin{array}{l}\text { ポアソン比 } \\
v\end{array}$ \\
\hline \hline 1 & B & 23.197 & 23.760 & 5.437 & 3 & 13.0 & 粘性土 & 28.321 & 0.047 & 0.3 \\
\hline 2 & Ac & 23.760 & 21.530 & 2.230 & 2 & 13.0 & 粘性土 & 20.475 & 0.034 & 0.3 \\
\hline 3 & LM & 21.530 & 19.590 & 1.940 & 1 & 15.0 & 粘性土 & 11.760 & 0.020 & 0.3 \\
\hline 4 & To-s1 & 19.590 & 16.010 & 3.580 & 25 & 19.0 & 砂質土 & 154.440 & 0.140 & 0.3 \\
\hline 5 & To-s2 & 16.010 & 7.180 & 8.830 & 39 & 19.0 & 砂質土 & 220.424 & 0.200 & 0.3 \\
\hline 6 & To-c & 7.180 & -3.210 & 10.390 & 12 & 16.0 & 粘性土 & 85.852 & 0.143 & 0.3 \\
\hline 7 & To-s3 & -3.210 & -5.080 & 1.870 & 32 & 19.0 & 砂質土 & 188.160 & 0.171 & 0.3 \\
\hline 8 & To-g & -5.080 & -6.310 & 1.230 & 47 & 19.0 & 砂質土 & 255.909 & 0.233 & 0.3 \\
\hline 9 & To-s4 & -6.310 & -11.880 & 5.570 & 45 & 20.0 & 砂質土 & 247.160 & 0.225 & 0.3 \\
\hline
\end{tabular}


図-14 に地盤を含めた橋軸方向載荷の解析モデルを示 す. 地盤の奥行きは 3 次元モデルと 2 次元モデルが工学 的に等価と考えられるフーチング幅とし，橋軸方向載荷 の解析モデルでは $11.0 \mathrm{~m}$ ，橋軸直角方向載荷では $17.5 \mathrm{~m}$ とした．地盤高さは，支持層以深の影響が少ないと考え られる杭の押抜きせん断の影響範囲とされる $3 D(D$ : 杭径） ${ }^{13)}$ を考慮し，地表面から $N$ 值が 45 の地層までの 地盤厚である約 $41 \mathrm{~m}$ とし, 地盤の全幅は十分に広い地 盤厚さの 5 倍とした ${ }^{14)}$. 載荷高さは，上部工および橋脚 をモデル化したレベル 2 地震動時の動的解析から得られ た曲げモーメントとせん断力の関係より $11.649 \mathrm{~m}$ とした. また，載荷レベルは，その動的解析から得られた最大せ ん断力に対する比率とし, 図-8に示すとおり, C 点まで 実験結果との整合性を有していることから，載荷レベル 150\%までを対象とした.

\section{（2）橋軸方向載荷の解析結果}

図-15に橋軸方向載荷時の載荷レベル-載荷点変位関 係，表-7 に各部位の損傷進展状況を示す. せん断力載 荷レベル 100\%以下では，既設杭，新設杭，フーチング のコンクリート部にひび割れが発生し，既設杭では軸方 向鉄筋が一部降伏する，載荷レベルが $100 \%$ を超えると，
既設杭のせん断補強筋が降伏した後，新設杭の軸方向鉄 筋，せん断補強筋が順に降伏寸る. 一方，橋脚の初降伏 は拘束鉄筋の初降伏後に発生し，フーチング上側鉄筋， 鋼製格子部材の順に初降伏する。また，載荷レベルが 150\%までは載荷点における急激な変位増加がないこと より，基礎全体としては降伏していないと考えられる ${ }^{15}$.

図-16〜図-18に載荷レベルが 100\%，150\%における変 形図，ひび割れ分布図および鉄筋降伏困を示す。載荷レ ベルを増加させると，合成構造フーチングでは鋼製格子 部材下側の RC 部に損傷が進展する. また, 図-16 の変 形図より，スウェイ挙動がほとんど見られないこと，曲 げひび割れ，軸方向鉄筋の降伏が発生していることから， 杭では曲げ変形が卓越していることがわかる.よって, 杭の顕著なせん断変形は見られないと考えられる.さら に，載荷レベルを増加させていくと，鋼製橋脚部が降伏 に至るため，損傷は橋脚基部に集中することが考えられ る.

図-19 に橋脚の初降伏時の主応力ベクトル図を示す. 橋脚の初降伏の発生箇所は鋼製格子部材との交差部であ る. また，図-20 に既設杭・新設杭の鉄筋降伏を示す. $\mathrm{A}$ 部では既設杭の杭頭部の軸方向鉄筋とせん断補強鉄筋 が降伏し，B部で既設杭の軸方向鉄筋， C 部では新設杭

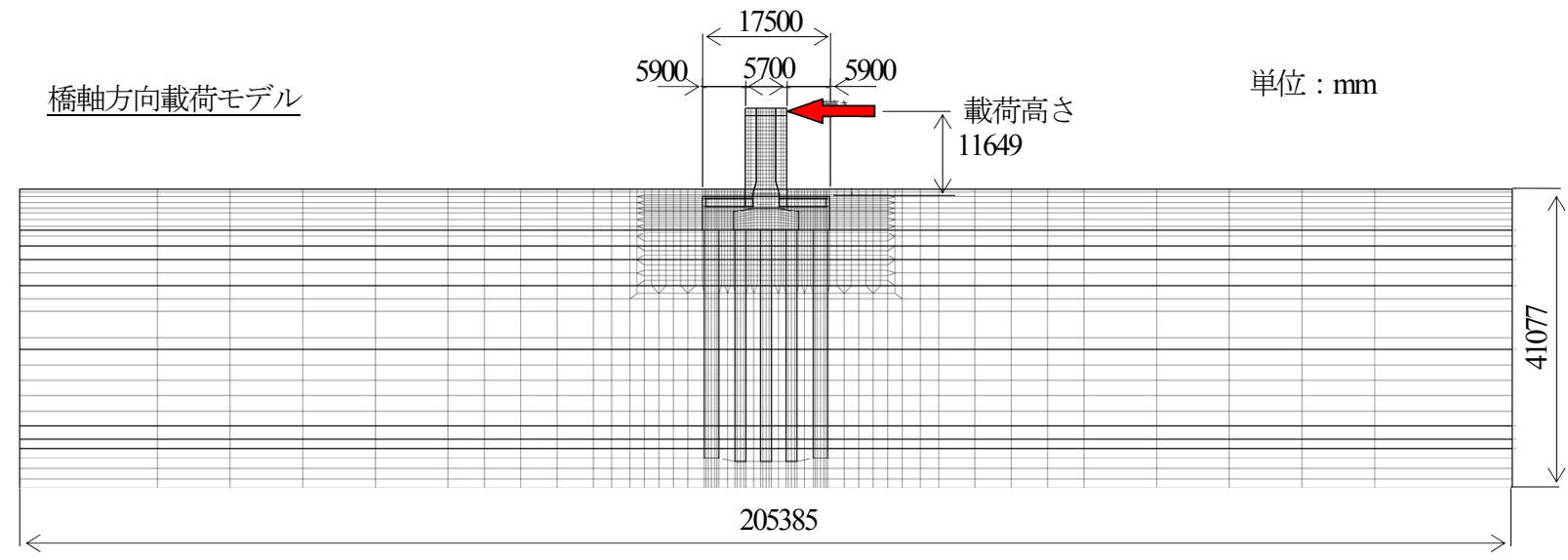

図-14 2 次元静的非線形 FEM解析モデル（橋軸方向）

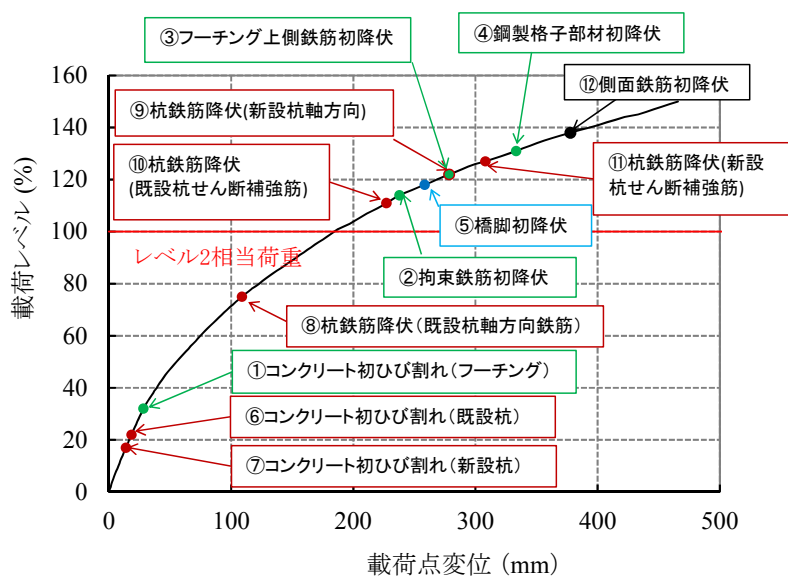

表-7 各部位の損傷進展状況

\begin{tabular}{|c|c|c|}
\hline 部位 & 損傷状況 & $\begin{array}{l}\text { 載荷 } \\
\text { レベル(\%) }\end{array}$ \\
\hline \multirow{4}{*}{$\begin{array}{c}\text { 合成構造フーチング上側 } \\
\text { (新設フーチング) }\end{array}$} & (1)コンクリート初ひび割れ & 32 \\
\hline & (2)拘束鉄筋 初降伏 & 114 \\
\hline & (3)フーチング上側鉄筋 初降伏 & 122 \\
\hline & (4)鋼製格子部材 初降伏 & 131 \\
\hline 橋脚 & (5)橋脚基部 鋼材初降伏 & 118 \\
\hline \multirow{6}{*}{ 杭 } & (6コンクリート初ひび割水(既設杭) & 22 \\
\hline & (7コンクリート初ひび割れ(新設杭) & 17 \\
\hline & 8杭鉄筋降伏(既設杭軸方向鉄筋) & 75 \\
\hline & 9杭鉄筋降伏(新設杭軸方向鉄能) & 122 \\
\hline & (10杭鉄筋降伏(既設杭せん断補強筋) & 111 \\
\hline & (11)杭鉄筋降伏(新設杭せん断補強筋) & 127 \\
\hline $\begin{array}{c}\text { 合成構造フーチング下側 } \\
\text { (既設フーチング) }\end{array}$ & (12)側面鉄筋 & 138 \\
\hline
\end{tabular}

図-15 載荷レベルー載荷点変位の関係（橋軸方向載荷） 
の杭頭部の軸方向鉄筋がいずれも降伏する．また，図21 にフーチングの鉄筋降伏を示寸．フーチング側面鉄

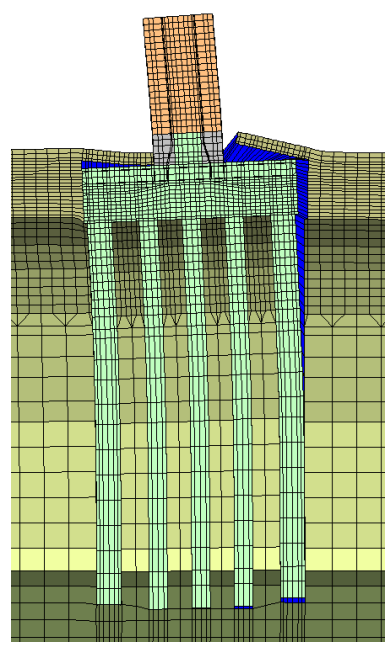

(a) 載荷レベル $100 \%$

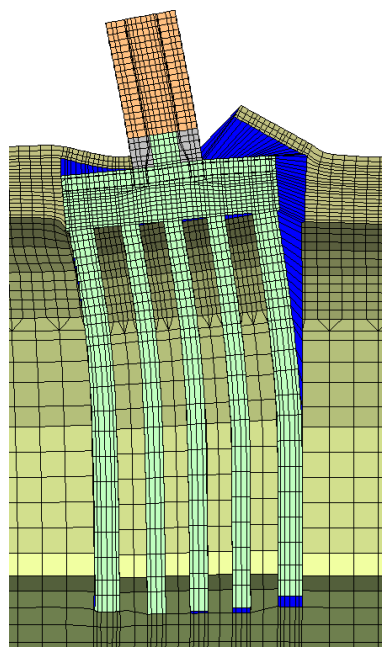

(b) 載荷レベル $150 \%$
図-16 変形図（変形量は 10倍に拡大）

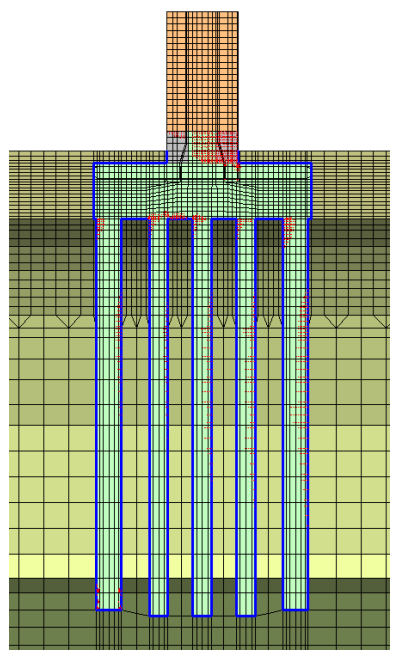

(a) 載荷レベル $100 \%$

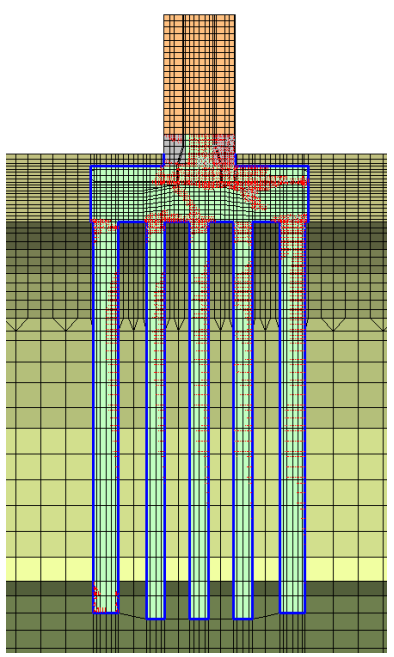

(b) 載荷レベル $150 \%$
図-17 ひび割れ分布図

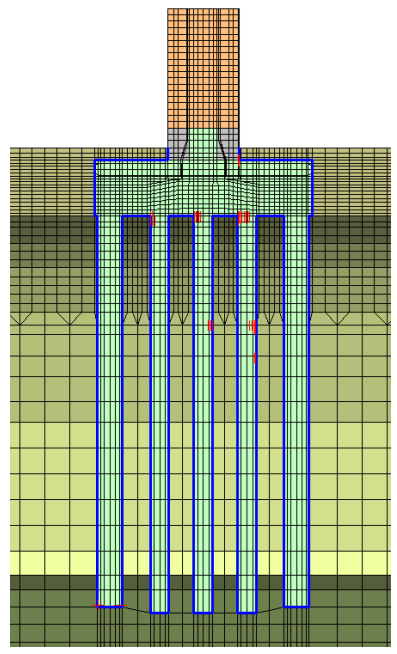

(a) 載荷レベル $100 \%$

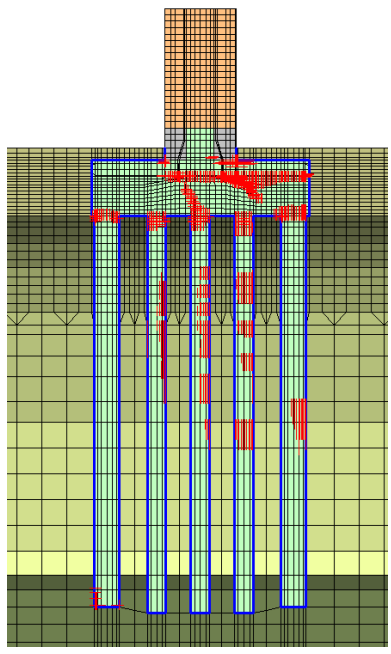

(b) 載荷レベル $150 \%$
図-18 鉄筋降伏図
筋は載荷レベル $138 \%$ から A 部において下側から上方に 向かって降伏が進展するが，下面鉄筋は降伏していない ことがわかる。

\section{（3）橋軸直角方向載荷の解析結果}

図-22 に橋軸直角方向載荷時の載荷レベル一載荷点変 位関係，表-8 に各部位の損傷進展状況を示す．載荷レ ベル 100\%までは, 既設杭, 新設杭, フーチングコンク リート部にひび割れが発生し，既設杭では軸方向鉄筋が 一部降伏する．載荷レベル 100\%を超えると，橋脚の初 降伏は拘束鉄筋の初降伏後に発生し，フーチング上側鉄 筋，その後，鋼製格子部材が初降伏するが，杭に関して はせん断補強鉄筋の降伏は発生しないことが判明した. また，載荷点における急激な変位の増加が見られないこ とことから基礎全体としては降伏していないと考えられ る.

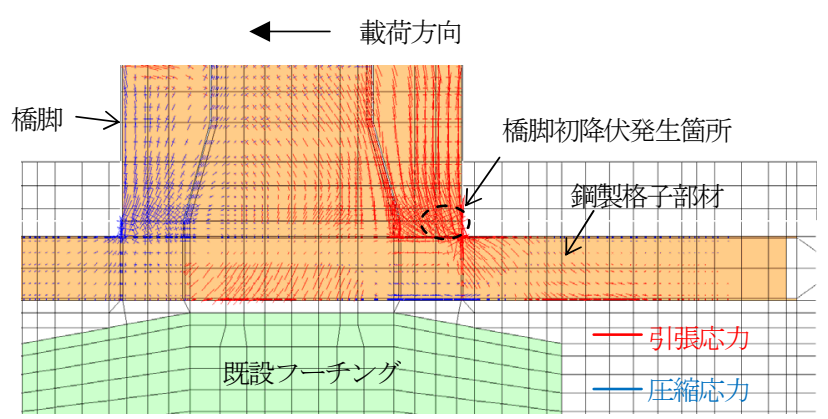

図-19 載荷レベル 118\%時の橋脚初降伏（主応力ベクトル図）

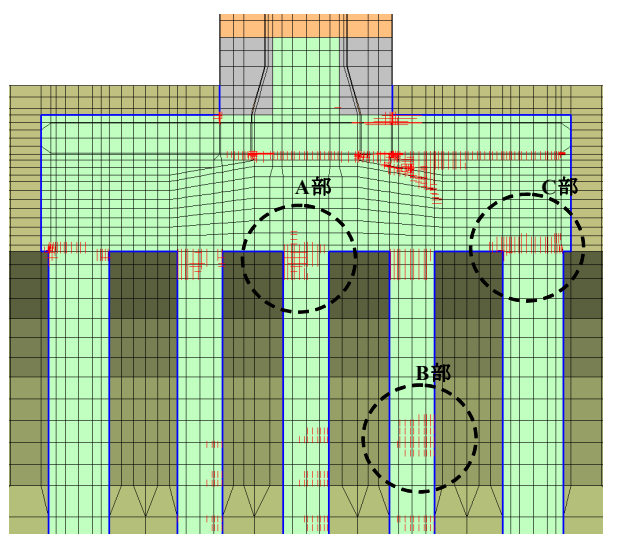

図-20 既設杭・新設杭の鉄筋降伏（載荷レベル 140\%)

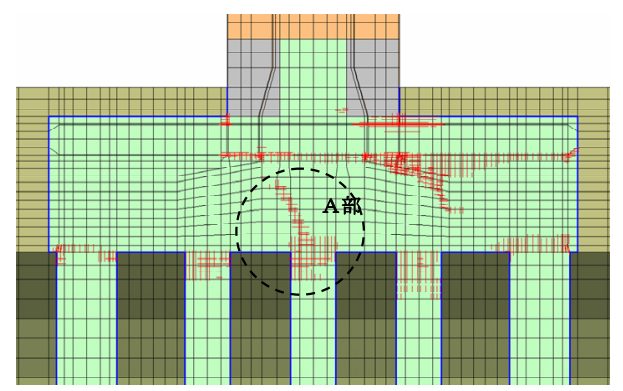

図-21 フーチングの鉄筋降伏（載荷レベル 150\%） 
図-23〜図-25に載荷レベルが 100\%，150\%における変 形図，ひび割れ分布図および鉄筋降伏図を示す．橋軸方 向載荷の解析結果と同様に，載荷レベルの増加とともに フーチングでは，鋼製格子部材下側の $\mathrm{RC}$ 部に損傷が進 展する．また，杭体では，いくつかの部位で曲げ降伏に 至るが，顕著なせん断変形は見られない.さらに，載荷 レベルを上げていくと，鋼製橋脚部が降伏に至るため損 傷は橋脚基部に集中することが考えられる．載荷レベル

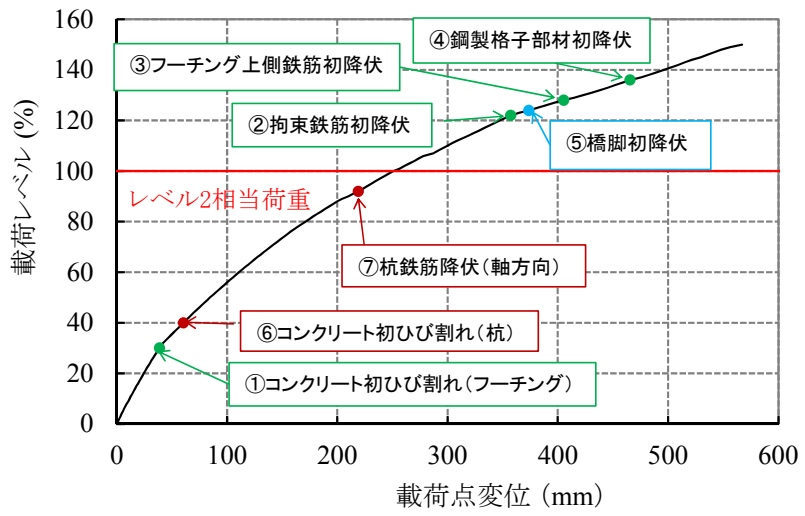

図-22 載荷レベル一載荷点変位関係（橋軸直角方向載荷）

\begin{tabular}{|c|c|c|}
\hline 部位 & 損傷状況 & $\begin{array}{c}\text { 載荷 } \\
\text { レベル }(\%)\end{array}$ \\
\hline \multirow{4}{*}{$\begin{array}{c}\text { 合成構造フーチング上側 } \\
\text { (新設フーチング) }\end{array}$} & (1)コンクリート初ひび割れ & 30 \\
\hline & (2)拘束鉄筇 初降伏 & 122 \\
\hline & (3)フーチング上側鉄筋 初降伏 & 128 \\
\hline & (4)鋼製格子部材 初降伏 & 136 \\
\hline 橋脚 & (5)橋脚 鋼材初降伏 & 124 \\
\hline \multirow{3}{*}{ 杭 } & (6)コンクリート初ひび割れ(杭) & 40 \\
\hline & (7)杭鉄筋降伏(軸方向鉄筋) & 92 \\
\hline & (8)杭鉄筇降伏(せん断補强鉄筋) & - \\
\hline $\begin{array}{c}\text { 合成構造フーチング下側 } \\
\text { (既設フーチング) }\end{array}$ & (9)側面鉄筋 & - \\
\hline
\end{tabular}

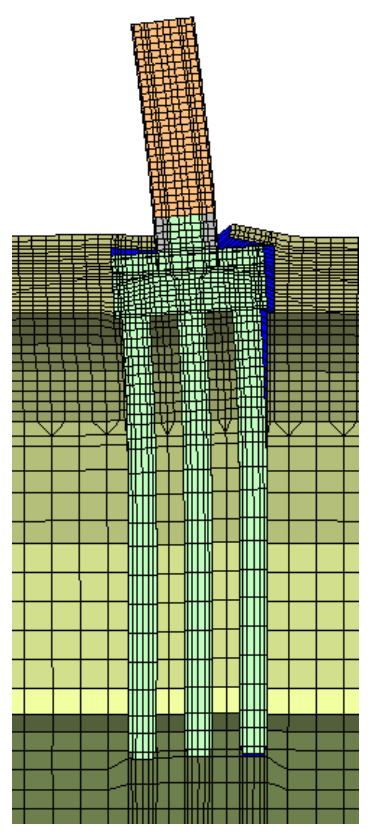

(a) 載荷レベル $100 \%$

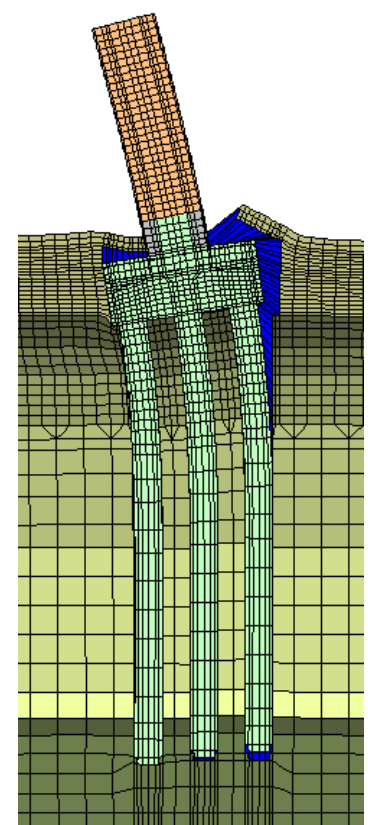

（b）載荷レベル $150 \%$
図-23 変形図（変形量は10倍に拡大）
100\%以下では，新設杭，フーチングコンクリート部に ひび割れが発生する．載荷レベルが $100 \%$ を超えると， 新設杭の軸方向鉄筋が降伏する. 図-26に橋脚の初降伏 時の主応力ベクトル図を示す．発生箇所は鋼製格子部材 との交差部である。また，図-27 に載荷レベル 150\%に おけるフーチングの鉄筋降伏の状況であるが，側面鉄筋 および下面鉄筋の降伏は見られない。
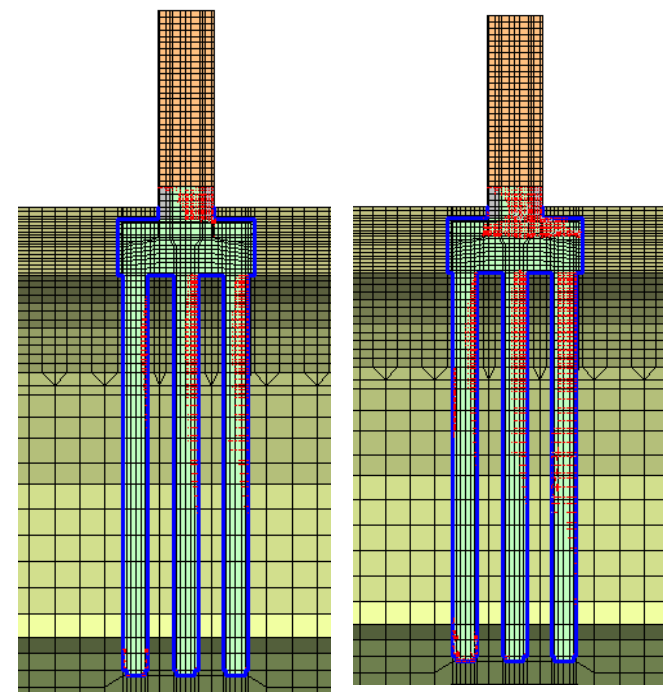

（a）載荷レベル $100 \%$ (b) 載荷レベル $150 \%$ 図-24ひひ割れ分布図

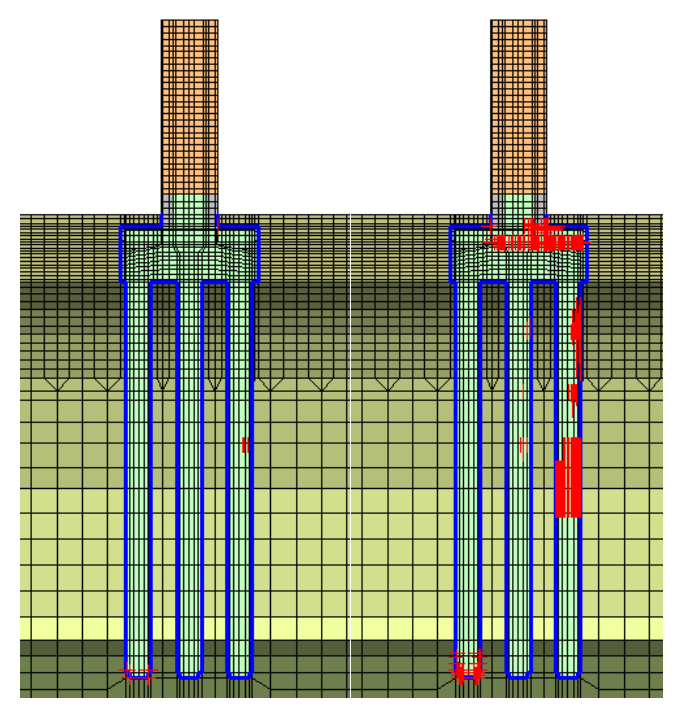

（a）載荷レベル $100 \% \quad$ (b) 載荷レベル $150 \%$ 図-25 鉄筋降伏図

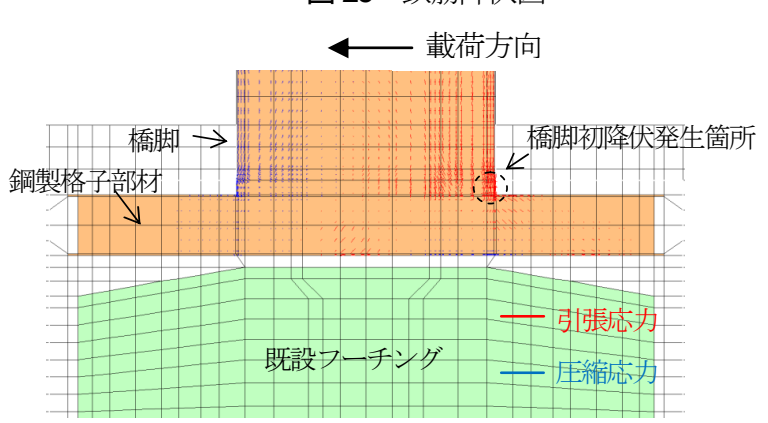

図-26 載荷レベル $125 \%$ 時の橋脚初降伏（主応力ベクトル図） 


\section{2 次元連成系動的非線形FEM 解析}

\section{(1) 解析概要}

\section{a) 解析モデル}

橋脚，合成構造フーチング，杭，周辺地盤に関する解 析モデルの要素分割, 各部位の材料構成則および材料特 性值は，静的解析と同一の考え方でモデル化した．図28 に橋軸直角方向の解析モデルを示す．ただし，動的 解析モデルにおいては，ダブルラケット型橋脚をモデル 化し，上層桁と下層桁の各々の上部工慣性力作用位置に 質量を配置している. 地盤のモデル化における静的解析 との違いは，地盤の側面と底面の境界条件を，それぞれ 混合境界と粘性境界としたことである。

地盤側面においては，混合境界により反射波を消去す る.波動が境界に到達したとき，境界が自由の場合には 波動は同位相で反射され，固定条件の場合には逆位相と なって反射される．混合境界は，この原理を用いて両者 を加え合わせることにより反射波を消去する手法である. 解析モデルでは, 地盤幅を $1 / 2$ ずつ分離し, 片側端部の 節点を水平方向に固定，もう一方の端部の節点を鉛直方 向に固定している．地盤底面においては，解析領域に生 じた反射波の地下一の逸散を表現するために，時刻歷解 法では粘性境界を設けることが多い，本検証においても， 表-9 に示寸特性值の粘性境界を地盤底面に設定した ${ }^{15}$. これにより，せん断粘性減衰係数 $\mu_{\mathrm{s}}$ と接線方向速度加 らせん断応力, 粘性減衰係数 $\mu_{n}$ と鉛直方向速度から鉛 直応力を境界面に与えることができる.

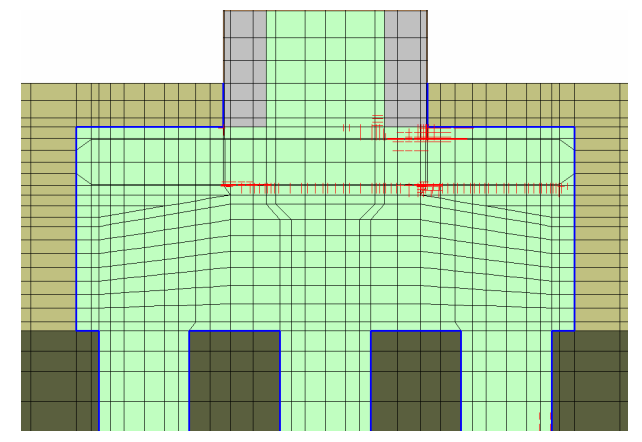

図-27 フーチングの鉄筋降伏（載荷レベル 150\%)

\section{b) 荷重載荷条件}

動的解析の初期状態は, サンドイッチ工法による施工 ステップに基づき算出した初期応力状態を再現するため の節点荷重を橋脚の節点に載荷する. その荷重強度は静 的解析と同一とした．上部工分担重量は，3 次元骨組み モデルを用いて算出し，上部工慣性力作用位置は上層椼 と下層桁各々で橋軸方向は支承位置, 直角方向は床版下 面とした. 構造物一地盤の連成系解析モデルを用いて時 刻歴応答解析を実施する際, 地震波の入力位置は, 基礎 構造の地震時挙動を詳細に検証するため, 第 4 砂質土層

$(N$ 值 $=45$, せん断弾性波速度 $=$ 約 $300 \mathrm{~m} / \mathrm{s})$ 下端を工学 的基盤面とした. また, 道路橋示方書・同解説 $\mathrm{V}$ 耐震 設計編（2012 年 3 月）では，40m以深の設計基盤面にお ける入力地震波として設定されたものはなく，I 種地盤 を基盤面が露頭した地盤とみなし，そこで設定されてい る地表面波を基盤面波として用いることとした．図-29 に I 種地盤用レベル 2 地震動（タイプ II） 3 波 16$)$ のうち の神戸海洋気象台地盤上 NS 成分（II-I-1）を示す。

\section{（2）橋軸方向載荷結果}

図-30 に上記 3 つ地震波の中で変位量が最大值を示 寸 II-I-1 を入力した場合の上層枌慣性力作用位置およ び杭頭における変位の時刻歴を示寸，なお，変位は杭先 端に対する相対変位である，以下においては，II-I-1 の地震波について解析結果を示す.

図-31〜図-33に，変形図，ひび割れ分布図，鉄筋降伏 図を示寸．合成構造フーチングの鋼製格子部材周辺に損 傷は生じていないことが確認できる，一方，橋脚基部最 大変位において既設杭は杭頭だけでなく杭全体に鉄筋の 降伏範囲が広がっており, 新設杭についても主に杭頭部 において鉄筋降伏が集中している．また，フーチングの 側面鉄筋は降伏するが，下面鉄筋の降伏は見られない．

表-10 に損傷発生時刻を示寸.

表-9 粘性境界の特性值

\begin{tabular}{|l|r|r|}
\hline & $\begin{array}{c}\text { せん断粘性隇衰係数 } \mu_{s} \\
\left(\times 10^{-3} \mathrm{~N} \cdot \mathrm{s} / \mathrm{mm}^{3}\right)\end{array}$ & $\begin{array}{c}\text { 粘性減衰係数 } \mu_{n} \\
\left(\times 10^{-3} \mathrm{~N} \cdot \mathrm{s} / \mathrm{mm}^{3}\right)\end{array}$ \\
\hline 底面粘性境界 & 0.71 & 2.35 \\
\hline
\end{tabular}

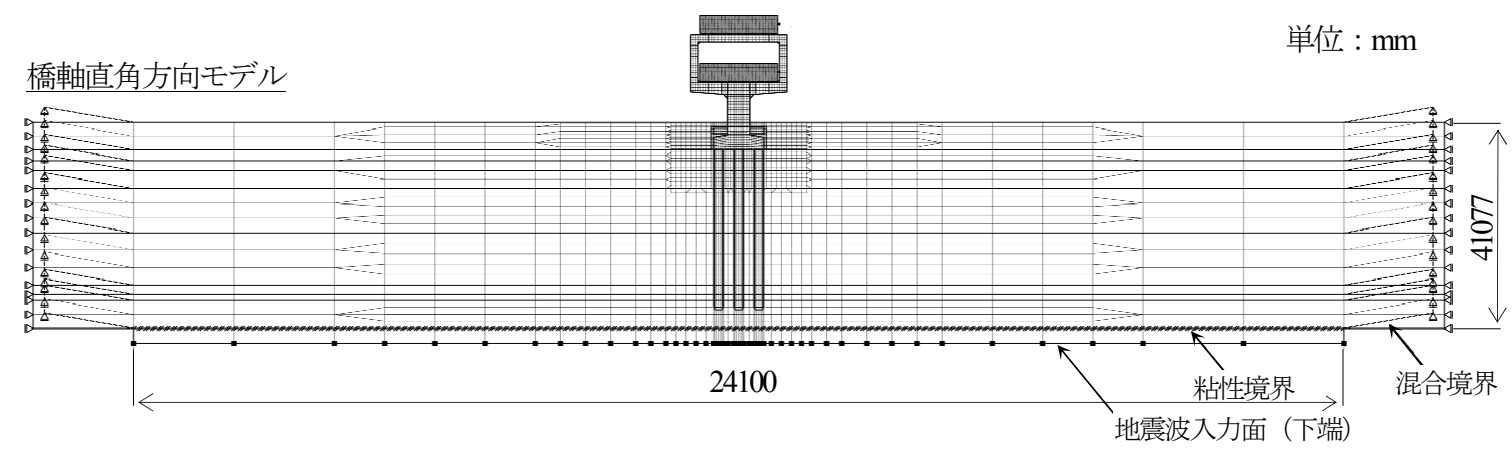

図-28 2 次元動的非線形 FEM解析モデル（橋軸直角方向） 


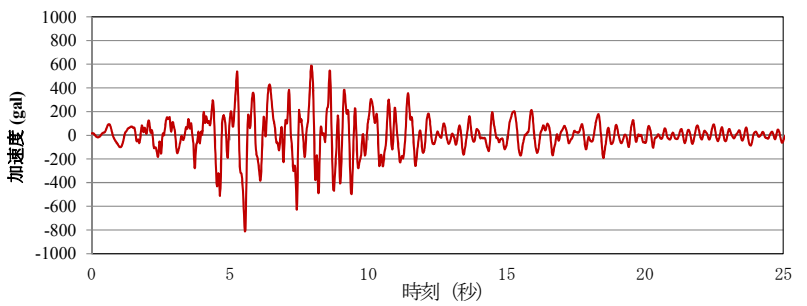

図-29 神戸海洋気象台地盤上NS 成分（II - I -1）

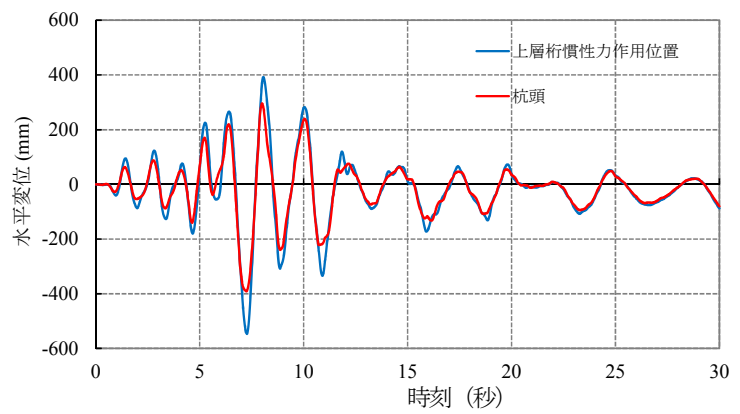

図-30 上層桁慣性力位置および杭頭における水平 変位の時刻歴応答（橋軸方向載荷）

\begin{tabular}{|c|c|c|}
\hline 部位 & 損傷状況 & $\begin{array}{l}\text { 発生時刻 } \\
\text { (秒) }\end{array}$ \\
\hline \multirow{4}{*}{$\begin{array}{c}\text { 合成構造フーチング上側 } \\
\text { (新設フーチング) }\end{array}$} & (1)コンクリート初ひび割れ & 5.11 \\
\hline & (2)拘束鉄笳＼cjkstart初降伏 & - \\
\hline & (3)フーチング上側鉄筋 初降伏 & - \\
\hline & (4)鋼製格子部材＼cjkstart初降伏 & - \\
\hline 橋脚 & (5)橋脚基部 鋼材初降伏 & - \\
\hline \multirow{6}{*}{ 杭 } & (6)コンクリート初ひび割れ（既設杭） & 0.80 \\
\hline & (7)コンクリート初ひび割れ（新設杭） & 0.75 \\
\hline & 8)杭鉄筋降伏（既設杭軸方向鉄筋） & 1.33 \\
\hline & (9)杭鉄筋降伏（新設杭軸方向鉄筋） & 2.80 \\
\hline & (10)杭鉄筋降伏（既設杭せん断補強鉄筋） & 5.05 \\
\hline & (11)杭鉄笳降伏（新設杭せ几断補強鉄筋） & 3.23 \\
\hline $\begin{array}{c}\text { 合成構造フーチング下側 } \\
\text { (既設フーチング) } \\
\end{array}$ & (12)側面鉄筋 & 10.87 \\
\hline
\end{tabular}

以上より，杭鉄筋の降伏はあるものの，図-30 に示寸 ように上層桁慣性力作用位置および杭頭における変位の 急増が見られないことから，基礎全体としては降伏して いないと考えられる.

\section{（3）橋軸直角方向載荷結果}

図-34 に上層桁慣性力作用位置および杭頭の変位時刻 歴を示す，なお，変位は杭先端に対する相対変位である． 最大変位時の変位および時刻は橋軸方向載荷と同様に, II-I-1 の地震波が最大変位を示したので，II-I-1 に ついて解析結果を示寸，図-35～図-37 に変形図，ひび割 れ分布図，鉄筋降伏図，表-11 に損傷発生時刻を示寸. 橋軸直角方向載荷においても，橋軸方向載荷と同様に， 合成構造フーチングの鋼製格子部材周辺に損傷は生じず, 杭に損傷が生じていることがわかる. また，フーチング の側面鉄筋および下面鉄筋の降伏は見られない.

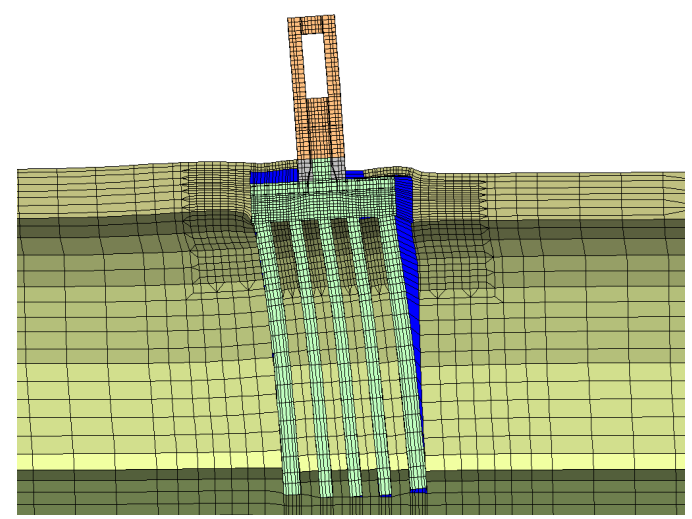

図-31 変形図（変形量は10倍に拡大，上層桁慣性力 作用位置変位最大時，7.26秒）

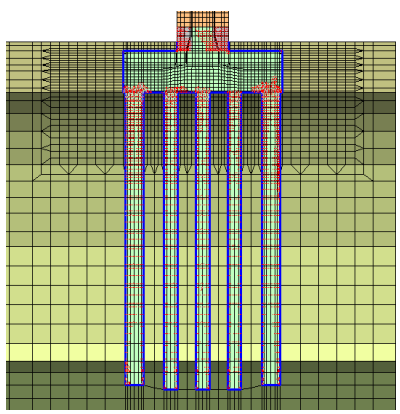

(a) 橋脚基部最大変位， 7.25 秒

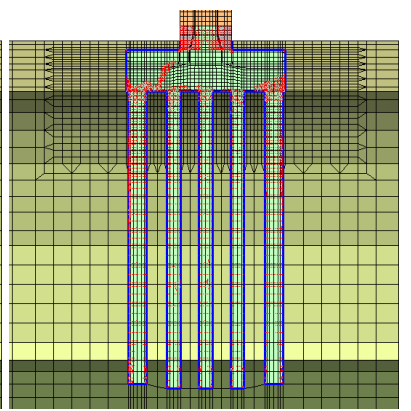

(b) 地震波形 30 秒終了
図-32 ひび割れ分布図

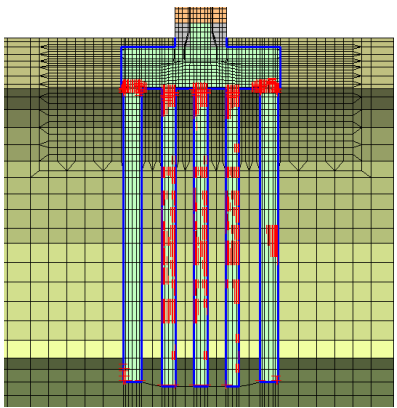

(a) 橋脚基部変位最大, 7.25 秒

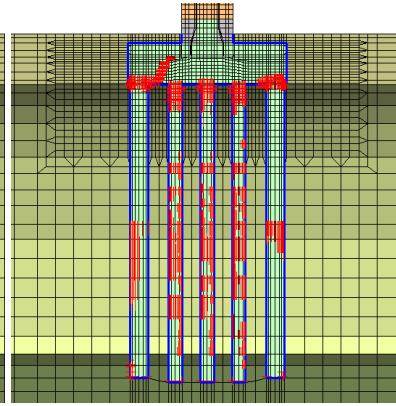

(b) 地震波形 30 秒終了
図-33 鉄筋降伏図

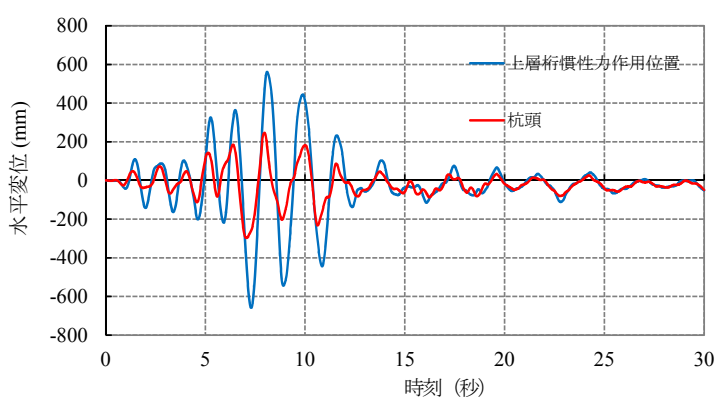

図-34 上層桁慣性力作用位置および杭頭における水 平変位の時刻歴応答（橋軸直角方向載荷）

以上より，杭鉄筋の降伏はあるものの，図-34 に示寸 ように，上層桁慣性力作用および杭頭における変位の急 増が見られないことから，基礎全体としての降伏はして いないと考えられる。 
表-11 損傷発生時刻

\begin{tabular}{|c|c|c|}
\hline 部位 & 損傷状況 & $\begin{array}{l}\text { 発生時刻 } \\
\text { (秒) }\end{array}$ \\
\hline \multirow{4}{*}{$\begin{array}{c}\text { 合成構造フーチング上側 } \\
\text { (新設フーチング })\end{array}$} & (1)コンクリート初ひび割れ & 1.51 \\
\hline & (2)拘束鉄筋＼cjkstart初降伏 & - \\
\hline & (3)フーチング上側鉄筋 初降伏 & - \\
\hline & (4)鋼製格子部材＼cjkstart初降伏 & - \\
\hline 橋脚 & (5)橋脚基部 鋼材初降伏 & - \\
\hline \multirow{3}{*}{ 杭 } & (6)コンクリート初ひび割れ（杭） & 0.74 \\
\hline & 8)杭鉄筋降伏（軸方向鉄筋） & 4.76 \\
\hline & (11)杭鉄筋降伏（せん断補強鉄筋） & 5.64 \\
\hline $\begin{array}{c}\text { 合成構造フーチング下側 } \\
\text { (既設フーチング) }\end{array}$ & (12)側面鉄筋 & - \\
\hline
\end{tabular}

- : 損傷なし

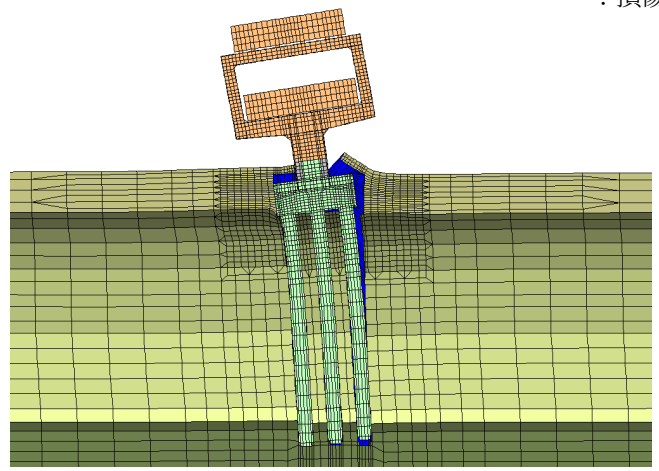

図-35 変形図（変形量は 10 倍に拡大，上層桁 慣性力作用位置変位最大，7.30秒）

\section{5. 既設構造物と一体化する下部構造系の設計の 方向性}

静的・動的解析の実施により，設定した下部構造系の 性能は確保できていることが検証できた。レベル 2 地震 動時においては，合成構造フーチングの損傷はフーチン グ上面のコンクリートひび割れに過ぎない. しかし，新 設杭はレベル 2 地震動時で降伏を許容しているため, 主 に杭頭部で鉄筋降伏などの損傷が発生する. 一方，既設 杭は，軸方向鉄筋量および帯鉄筋量が現行基準と比較し て少ないため，新設杭と比較して広範囲にわたり損傷が 発生する. しかし，この結果のみでは安全性，供用性の 判断は困難である。 そこで，本検証では既設杭，新設杭， 合成構造フーチング，橋脚，周辺地盤を含めた下部構造 系を対象とした構造物一地盤連成系静的解析を行い，慣 性力作用位置における荷重一変位関係で急激な変位増加 がないことを確認し，基礎全体としては降伏していない と評価している.

次に，どのようにして既設構造物，特に既設杭に関し て損傷を制御するかが重要である．既設杭は新設杭の内 側にあるため, 損傷発見, 補修・補強が極めて困難であ る. 合成構造フーチングの一部を構成する上面増厚によ り，施工が極めて困難な既設フーチング部の下面曲げ補 強および既設杭の負担軽減が可能となる. さらに，周辺 地盤による拘束効果を考慮すれば，既設杭は杭頭部およ

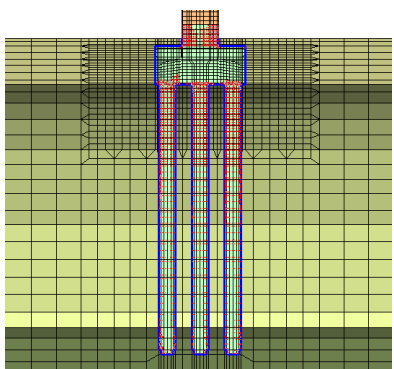

（a） 橋脚基部変位最大，7.15 秒

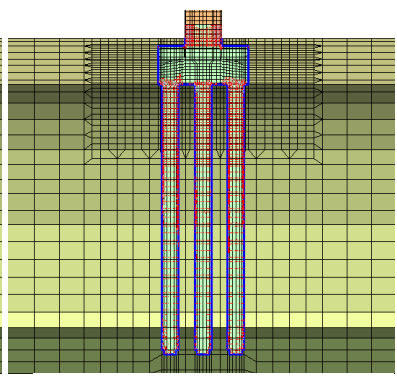

(b) 地震波形 30 秒終了

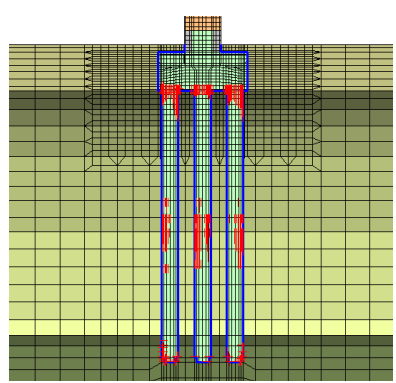

（a） 橋脚基部変位最大， 7.15 秒

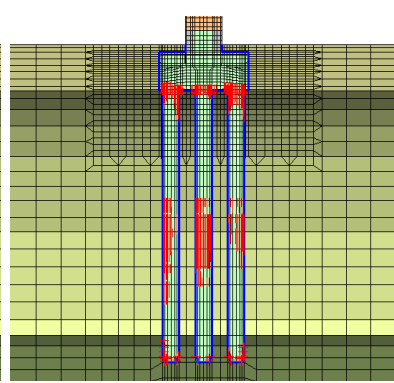

(b) 地震波形 30 秒終了
図-37 鉄筋降伏図

び杭本体で損傷が発生しても，既設杭のせん断変形の進 展は抑制されると考えられる。また，上面増厚部は土被 り確保のため深さ方向の制限を受けるため，鋼製格子部 材を平面的にフーチング全面配置とすることにより，鋼 製橋脚に作用する地震力を橋脚基部で岡結している鋼製 格子部材を介して新設杭に伝達し，既設杭の負担軽減が 図れる.ただし，本解析結果において示したとおり，レ ベル2地震動時相当荷重を超えてから，鋼製橋脚の降伏 が新設フーチング中に位置する鋼製格子部材と剛結する 橋脚基部で発生するため, 補修・補強ができるように地 表面よりも上で制御できるようにすることが課題である.

\section{6. 結論}

本研究では，合成構造フーチングを有する橋脚基礎の 地震応答を検証するために，2次元連成系静的・動的非 線形FEM解析を実施した. 以下に得られた知見を示す.

1）静的解析においては，橋軸方向・橋軸直角方向載荷 ともに，載荷レベルが $100 \%$ を超えてから，拘束鉄 筋，鋼製橋脚基部，フーチング上側鉄筋，鋼製格子 部材の順に初降伏が発生する.

2）橋軸方向載荷では，載荷レベル $75 \%$ で既設杭の軸方 向鉄筋が降伏するが，既設杭のせん断補強鉄筋，新 設杭の軸方向鉄筋，せん断補強鉄筋は，載荷レベル 100\%を超えてからこの順で降伏が発生する．また， フーチング側面鉄筋は降伏するが，下面鉄筋の降伏 は見られない。

3）橋軸直角方向載荷では，載荷レベル $92 \%$ で軸方向鉄 
筋が降伏するが，せん断補強鉄筋は $150 \%$ までは降 伏しない。

4）載荷レベルを $150 \%$ まで上げても，橋軸方向・橋軸 直角方向載荷ともに，慣性力作用位置における急激 な変位増加がなく，基礎全体としては降伏しないと 考えられる.

5）一方，動的解析においては，橋軸方向載荷では，既 設杭・新設杭ともに軸方向鉄筋・せん断補強鉄筋は 降伏し，フーチング側面鉄筋も降伏寸る．また，橋 軸直角方向載荷では杭の軸方向鉄筋・せん断補強鉄 筋ともに降伏するが，フーチング側面鉄筋は降伏し ない.

6）レベル 2 地震動時における既設杭の杭頭部について は, 橋軸方向・橋軸直角方向載荷の静的 ・ 動的解析 ではいずれも杭頭部に損傷は集中しているが，周辺 の地盤抵抗により，顕著なせん断変形は見られない，

7）静的・動的解析における橋軸・橋軸直角方向載荷の いずれも，フーチング下面鉄筋の降伏は発生してい ない．これは合成構造フーチングにおける上面側の 増厚効果が寄与していると考えられる.

8）動的解析においても，橋軸方向・橋軸直角方向載荷 ともに，慣性力作用位置における急激な変位増加が なく．基礎全体としては降伏しないと考えられる.

この成果を踏まえ，今後直面することが多くなる既設 構造物を活用した下部構造系の設計法について検討を重 ねていきたい。

\section{参考文献}

1) 伊原茂，中野博文，内海和仁，武田篤史，天野寿宣， 斉藤成彦：鋼製格子部材を埋設した合成構造フーチ ングの耐荷性能に関する実験的研究, 構造工学論文 集, Vol.60A, pp. 848-860, 2014.3.

2) 伊原茂, 中野博文, 齋藤隆, 天野寿信, 斉藤成彦 : アンカーフレーム代替機能を有する合成構造フーチ ングの耐荷性能に関する実験的研究, 土木学会論文 集, Vol. 71, No.1, pp. 55-71, 2015.2.
3)牧剛史, 睦好宏史, 前川宏一： RC 杭体一地盤相互作 用解析における線材モデルの適用性, 土木学会論文 集, No.746/V-61, pp.57-70, 2003.11.

4) 牧剛史, 土屋智史, 渡辺忠朋, 前川宏一: 3 次元非線 形有限要素法を用いた $\mathrm{RC}$ 杭基礎一地盤系の連成地震 応答解析, 土木学会論文集, Vol.64, No.2, pp.192-207, 2008.4 .

5) 岡村甫, 前川宏一 : 鉄筋コンクリートの非線形解析 と構成則，技報堂出版，1991.5.

6) 土屋智史, 中浜俊介, 前川宏一：梁のせん断耐力と 斜めひび割れの 3 次元分布に及ぼす側方筋の効果, コンクリート工学年次論文集, Vol.23, No.3, pp.9971002, 2001.6

7) 土木学会 : 2012 年制定コンクリート標準示方書（設 計編），pp.258-269，2013.3.

8) Ohsaki, Y. : Some Notes on Masing's Law and non-linear response of soil deposits, Journal of the Faculty of Engineering, The University of Tokyo (B), Vol.35, No.4, pp.513-536, 1980.9

9) 土木学会コンクリート委員会 : 非線形解析によるコ ンクリート構造物の性能照査一手順と検証例・照査 例，コンクリート技術シリーズ 66, pp.20-39，2005.9.

10) 土木学会コンクリート委員会：コンクリート構造物 の耐震設計，コンクリート技術シリーズ 81 , III- 60 $\sim 99,2008.7$.

11) Shawky, A. and Maekawa, K. : Computational approach to path-dependent nonlinear RC/Soil interaction, Proc. of JSCE, No.532/V-30, pp.197-207, 1996.2.

12) 鉄道総合技術研究所: 鉄道構造物等設計標準 - 同解 説 基礎構造物・抗土圧構造物 : pp.208-214, 2000.6 .

13）日本道路協会 : 杭基礎設計便覧平成 18 年度改訂版, pp.409-413, 2007.1.

14) 土木学会コンクリート委員会 : 阪神淡路大震災の被 害分析に基づくコンクリート構造物の耐震性能照査 方法の検証一解析手法の適用と比較, コンクリート 技術シリーズ 49, pp.116-295, 2002.12.

15) 日本道路協会 : 道路橋示方書 - 同解説 $V$ 而震設計編, pp.235-250, 2012.3.

16) 日本道路協会 : 道路橋示方書 - 同解説 $V$ 而震設計編, pp.109-131, 2012.3.

(2015. 11. 5 受付, 2016.1.20 修正, 2016.2. 20 受理)

\title{
A STUDY ON SEISMIC RESPONSE OF PILE FOUNDATION AND THE HYBRID STRUCTURAL FOOTING OF DOUBLE RACEKT-TYPE STEEL PIERS
}

\author{
Shigeru IHARA, Hisatomo MATSUZAKI, Takashi SAITO, Satoshi TSUCHIYA \\ and Shigehiko SAITO
}

In this paper, seismic responses of RC piles and the hybrid structural footing foundation of the double racket-type steel piers are described by 2-D static and dynamic soil-structure coupled nonlinear FEM analyses in detail. Authors verified that the newly developed structure had enough load bearing capacity when the level II earthquake load was applied in the longitudinal and transverse directions. It is founded that shear deformation around the heads of the existing RC piles is not significant and the hybrid structural footing is also effective to reduce the stresses in the lower surface of the existing RC footing. It is confirmed the overall pile and footing foundations could keep stable even if some parts of the RC piles yielded under the level II earthquake. 